Provided for non-commercial research and education use. Not for reproduction, distribution or commercial use.

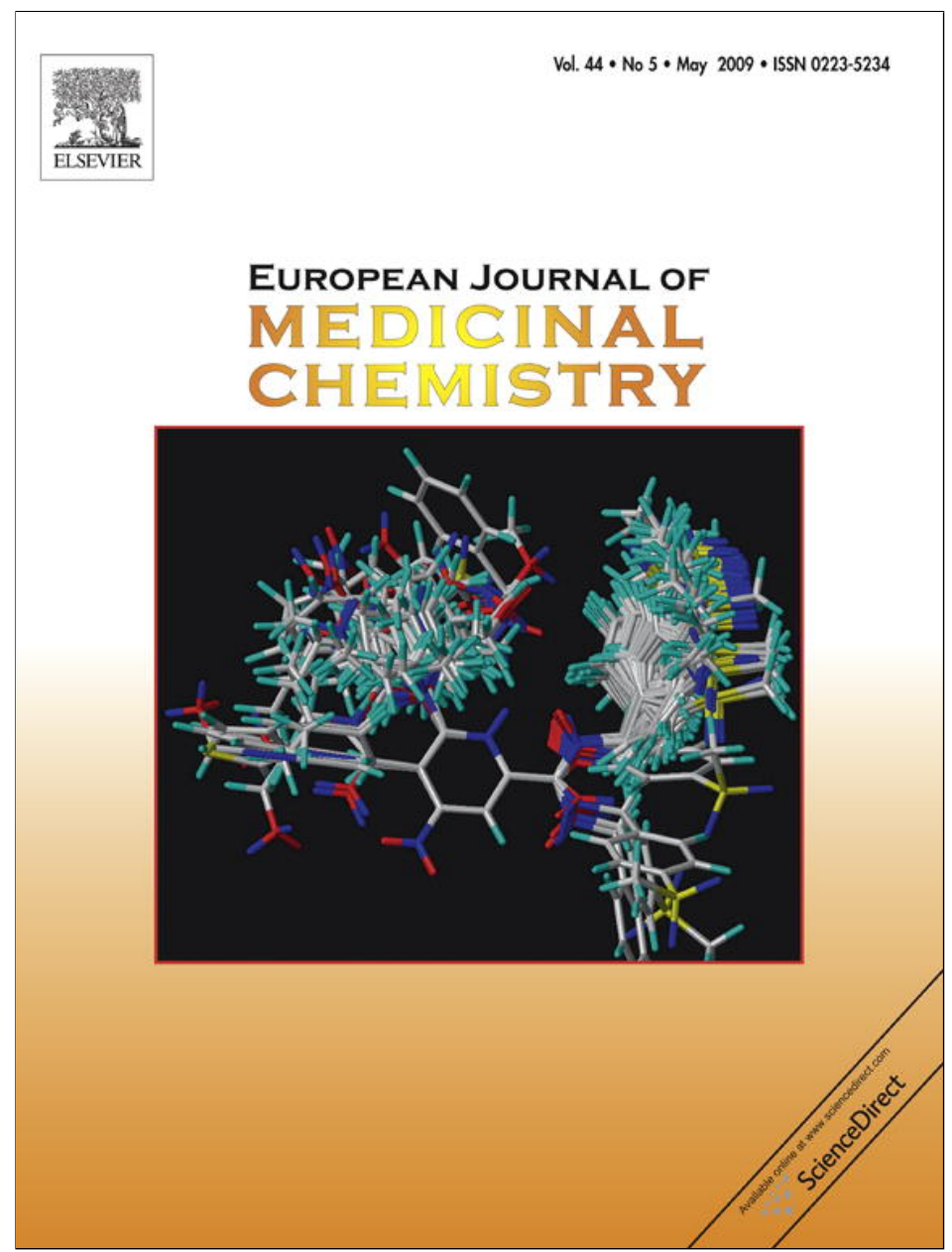

This article appeared in a journal published by Elsevier. The attached copy is furnished to the author for internal non-commercial research and education use, including for instruction at the authors institution and sharing with colleagues.

Other uses, including reproduction and distribution, or selling or licensing copies, or posting to personal, institutional or third party websites are prohibited.

In most cases authors are permitted to post their version of the article (e.g. in Word or Tex form) to their personal website or institutional repository. Authors requiring further information regarding Elsevier's archiving and manuscript policies are encouraged to visit:

http://www.elsevier.com/copyright 
Original article

\title{
Large ring 1,3-bridged 2-azetidinones: Experimental and theoretical studies
}

\author{
Allan Urbach ${ }^{\mathrm{a}}$, Georges Dive ${ }^{\mathrm{b}}$, Bernard Tinant ${ }^{\mathrm{c}}$, Valérie Duval ${ }^{\mathrm{b}}$, Jacqueline Marchand-Brynaert ${ }^{\mathrm{a}, *}$ \\ ${ }^{a}$ Université catholique de LouvainUnité de Chimie Organique et Médicinale, Bâtiment Lavoisier, Place Louis Pasteur $n^{\circ} 1,1348$ Louvain-la-Neuve, Belgium \\ ${ }^{\mathrm{b}}$ Université de LiègeCentre d'ingénierie des protéines, Bâtiment B6a, Allée du 6 Août, 4000 Sart-Tilman-Liège, Belgium \\ ${ }^{\mathrm{c}}$ Université catholique de LouvainUnité de Chimie Structurale et des Mécanismes Réactionnels, Bâtiment Lavoisier, Place Louis Pasteur ${ }^{\circ}$ 1, 1348 Louvain-la-Neuve, Belgium
}

\section{A R T I C L E I N F O}

\section{Article history:}

Received 19 June 2008

Received in revised form

6 October 2008

Accepted 10 October 2008

Available online 26 October 2008

\section{Keywords:}

Bicyclic $\beta$-lactam

RCM reaction

Conformational study

$A b$ initio reactivity

Serine-enzyme inhibition

\begin{abstract}
A B S T R A C T
The relationship between angular strain and (re)activity of bicyclic 2-azetidinones is still an open question of major concern in the field of penicillin antibiotics. Our study deals with original 13membered-ring 1,3-bridged 2-azetidinones related to the carbapenem family, and featuring a "planar amide" instead of the "twisted amide" typical of penam derivatives. The bicycles $\mathbf{1 1}$ and $\mathbf{1 2}$ were obtained from acetoxy-azetidinone 7, via the key-intermediate 10, by using the RCM (ring closing metathesis) strategy. Theoretical predictions and experimental results of hydrolysis showed that the large bicycle 12, endowed with high conformational flexibility, is more reactive than the bicycle 11, including a $\mathrm{C}=\mathrm{C}$ bond of $E$ configuration, and the monocyclic 2-azetidinone precursor $\mathbf{1 0}$. The processing of 2-azetidinones 10-12 in the active site of serine enzymes has been computed by $a b$ initio methods, considering three models. Due to geometrical parameters of the enzymic cavity (nucleophilic attack from the $\alpha$-face), precursor $\mathbf{1 0}$ was predicted more active than $\mathbf{1 1}$ and $\mathbf{1 2}$ in the acylation step by Ser-OH. Indeed, bicycles $\mathbf{1 1}$ and $\mathbf{1 2}$ are modest inhibitors of $\mathrm{PBP}_{2 \mathrm{a}}$, while $\mathbf{1 0}$ is a good to excellent inhibitor of $\mathrm{PBP}_{2 \mathrm{a}}$ and $\mathrm{R} 39$ bacterial enzymes.
\end{abstract}

(c) 2008 Elsevier Masson SAS. All rights reserved.

\section{Introduction}

Antibiotics of the penicillin family are characterized by the presence of a $\beta$-lactam ring involved into a quite rigid bicyclic structure (Scheme 1, 1 and $\mathbf{2}$ ). It is widely accepted that the high reactivity of $\beta$-lactam antibiotics results from the lack of amide resonance in the 2 -azetidinone ring [1-3]. In penams (1), penems $(2, \mathrm{X}=\mathrm{S})$ and carbapenems $\left(2, \mathrm{X}=\mathrm{CH}_{2}\right)$, the $\pi$ electrons of the $\mathrm{N}-$ $\mathrm{C}=\mathrm{O}$ function cannot be delocalized over the three atoms owing to the structural constraints which prevent the amide substituents to lie in the same plane. The deviation versus coplanarity (i.e. pyramidality of the bridge-head nitrogen atom) is usually expressed by Woodward's [4-6] or Burton's [7] parameters.

The experimental and theoretical interest of the scientific community in the so-called "twisted amides" [8] has been constant since more than 60 years, as exemplified with the recent achievement of the 2-quinuclidone (3) synthesis in 2006 [9]. In the field of antibiotics, [2] a lot of works has been devoted to the search of more strained, fused bicyclic $\beta-[10,11]$ and $\gamma-[12,13]$ lactam systems. However, there is still no clear relationship between the lactam structural features ( $N$-pyramidality, bond angles and distances), chemical reactivity and biological activity.

\footnotetext{
* Corresponding author. Fax: +32 10474168 .

E-mail addresses: gdive@ulg.ac.be (G. Dive), bernard.tinant@uclouvain.be (B. Tinant), jacqueline.marchand@uclouvain.be (J. Marchand-Brynaert).
}

Our aim is to explore a totally different route for designing reactive bicyclic $\beta$-lactams. During the 2 -azetidinone ring opening under nucleophilic attack (basic hydrolysis or processing by a serine enzyme), an important conformational reorganisation of the other ring has to occur. The conformational flexibility of this second ring, namely the capacity to adjust itself to new geometrical parameters, should decrease the activation barrier of the $\beta$-lactam N1-C2 bond cleavage. To investigate this idea, we decided to prepare large ring 1,3-bridged $\beta$-lactam compounds (Scheme 2) and to study their reactivity, theoretically and experimentally. In contrast with fused lactams, bridged lactams as potential antibiotics are scarcely described in the literature; we found only three relevant examples corresponding to skeletons 4 [14], 5 [15] and 6 [16], but these structures display high angular strain and therefore, twisted amide bonds (Scheme 1).

In this article, we illustrate the study of conformationally flexible 1,3-bridged $\beta$-lactams with the 13-membered-ring compounds 11 and 12 (Scheme 3) derived from acetoxy-azetidinone 7, commonly used as precursor of thienamycin derivatives (carbapenem family) [17]. We selected RCM reaction (Ring Closing Metathesis) [18-20] as key-step for forming the large ring (Scheme 2), the required precursor being readily accessible by sequential functionalisation of nitrogen $\mathrm{N} 1$ and deprotected hydroxyl group on $\mathrm{C} 5$. We chose acylation reactions to introduce the two side-chains for the following reasons: (i) the synthetic easiness providing a rapid access to compounds of interest; (ii) the 
<smiles>O=C1CC2SCCN12</smiles><smiles>[X]C1CC(=O)N1C=C</smiles><smiles>[Z]CC1CN2C(=O)C3[Y]CCCC3[SH]12</smiles><smiles>O=C1CCC2CCCCN12</smiles><smiles>O=C1CC2CCCN1C2</smiles><smiles>O=C1CC2CC=CN1CC2</smiles>

Scheme 1. Bicyclic lactams with "twisted amide" bond (skeletons are drawn with omitting the substituents).

potential biological activities of the novel $\beta$-lactams, since N1acylated compounds have been previously recognized as inhibitors of various proteases [21-24].

A complete comparative study of the chemical and biochemical reactivity of $\beta$-lactams 10-12 has been performed. Theoretical predictions could be experimentally confirmed, that pointed out the importance of conformational flexibility. Moreover, interesting activities for the inhibition of serine enzymes were recruited.

\section{Results and discussion}

\subsection{Synthesis (Scheme 3)}

Commercially available $(3 R, 4 R, 5 R)$ chiron 7 was transformed into precursor 10 in three steps with an overall yield of $72 \% . \mathrm{N}-$ Acylation with 4-pentenoyl chloride was conducted in refluxing dichloromethane (DCM), in the presence of pyridine. Silyl ether deprotection of $\mathbf{8}$ was not effective by using cesium fluoride in methanol, and gave poor yields by using tetrabutylammonium fluoride in aqueous acetic acid and THF solution [25]. The protocol established by Murakami et al. [26] for the synthesis of oxacephems afforded the best results: alcohol $\mathbf{9}$ was quantitatively obtained by treatment of $\mathbf{8}$ with $\mathrm{HCl}-\mathrm{AcOH}$ in acetonitrile at $0{ }^{\circ} \mathrm{C}$. The purity of crude $\mathbf{9}$, controlled by ${ }^{1} \mathrm{H}$ NMR, was judged adequate to directly perform the next step. Thus $\mathbf{1 0}$ resulted from the reaction of crude alcohol 9 with 4-pentenoyl chloride and pyridine in DCM at room temperature. After chromatographic purification, the product was recovered in $90 \%$ yield.

The RCM key step was readily performed under Ahn's conditions [27], i.e. with Grubbs catalyst of second generation (5 mol\%), in

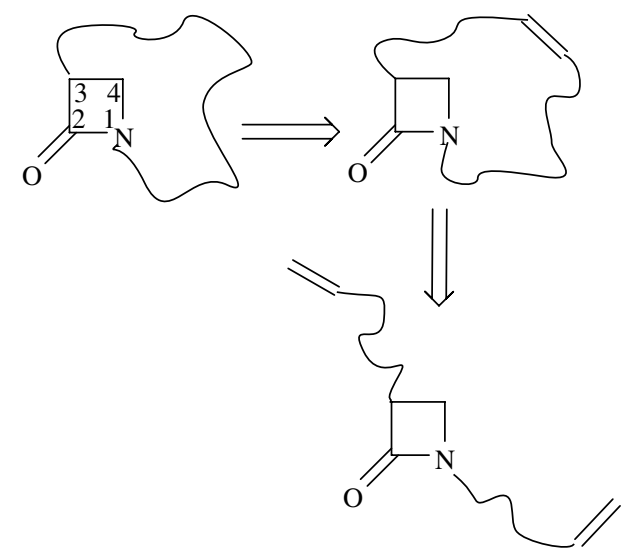

Scheme 2. General strategy towards large ring 1,3-bridged $\beta$-lactams.<smiles>CC(=O)O[C@H]1NC(=O)[C@@H]1[C@H](C)OC(C)C</smiles><smiles>C=CCCC(=O)N1C(=O)[C@H]([C@@H](C)OC(C)(C)C)[C@H]1OC(C)=O</smiles><smiles>C=CCCC(=O)N1C(=O)[C@H]([C@H](C)O)[C@H]1OC(C)C</smiles><smiles>C=CCCC(=O)O[C@@H](C)[C@H]1C(=O)N(CC)[C@@H]1OC(C)=O</smiles>

10<smiles>C[C@H](OC(=O)CC/C=C/CCC(=O)N1C(=O)[C@H](C)[C@H]1O)C(=O)O</smiles>

11(E isomer)<smiles></smiles>

Scheme 3. Synthesis of 13-membered 1,3-bridged 2-azetidinone. a) $\mathrm{Cl}-\mathrm{CO}-\left(\mathrm{CH}_{2}\right)_{2}$ $\mathrm{CH}=\mathrm{CH}_{2}$, pyridine, $\mathrm{CH}_{2} \mathrm{Cl}_{2}$, reflux or $20^{\circ} \mathrm{C}$; b) $\mathrm{HCl}-\mathrm{AcOH}(5: 7), \mathrm{CH}_{3} \mathrm{CN}, 0^{\circ} \mathrm{C}$; c) Grubbs catalyst (2.5 mol\%), toluene, $80^{\circ} \mathrm{C}$; d) $\mathrm{H}_{2}$, Pd-C, EtOAC, $20^{\circ} \mathrm{C}$.

diluted solution of $\mathbf{1 0}$ (5 mM in DCM), at room temperature. Only one cyclized compound was formed (TLC and NMR analysis of the crude mixture) corresponding to $\mathbf{1 1}$ with the $E$ configuration of the $\mathrm{C}=\mathrm{C}$ double bond $\left(\mathrm{J}_{\mathrm{H}, \mathrm{H}}=15.5 \mathrm{~Hz}\right)$. Purification by column chromatography on silica gel afforded $85 \%$ yield of $\mathbf{1 1}$ which structure was confirmed by X-ray diffraction analysis of a single crystal shown in Fig. 1. The main bond lengths, angles, torsions and distances from the plan, characteristic of the bicycle 11, are summarized in Table 1.

Finally, catalytic hydrogenation led quantitatively to the saturated bicyclic azetidinone 12.

All the spectroscopic data (Section 4) indicated that the azetidinones 10-12 are "non-twisted" amides (Table 2). The IR spectra showed very similar values of carbonyl stretching frequencies for monocyclic (10) and bicyclic compounds (11 and 12). The $\beta$-lactam protons $\mathrm{H} 3$ and $\mathrm{H} 4$ also displayed the same pattern for the three compounds 10-12, but differences arose for H5 proton of the 1hydroxyethyl side-chain between monocyclic (10) and bicyclic $\beta$-lactams $(\mathbf{1 1}, \mathbf{1 2})$. However, the two bicyclic derivatives are quite similar considering the dihedral angle $\mathrm{H} 4-\mathrm{C} 4-\mathrm{C} 5-\mathrm{H} 5$ (see $J$ values). The ${ }^{13} \mathrm{C}$ chemical shifts of the $\mathrm{C}=\mathrm{O}$ functions were found to be almost identical in compounds 10-12. The X-ray structure of $\mathbf{1 1}$ (Fig. 1) confirmed the planarity of the amide $\beta$-lactam bond. The typical features of $\mathbf{1 1}$ compared to classical penicillins (penams $\mathbf{1}$ [28] and penems 2 [29]) are summarized in Table 3: the large ring 1,3 bridged 2-azetidinone (11) is definitively not a penicillin-like $\beta$-lactam compound. 


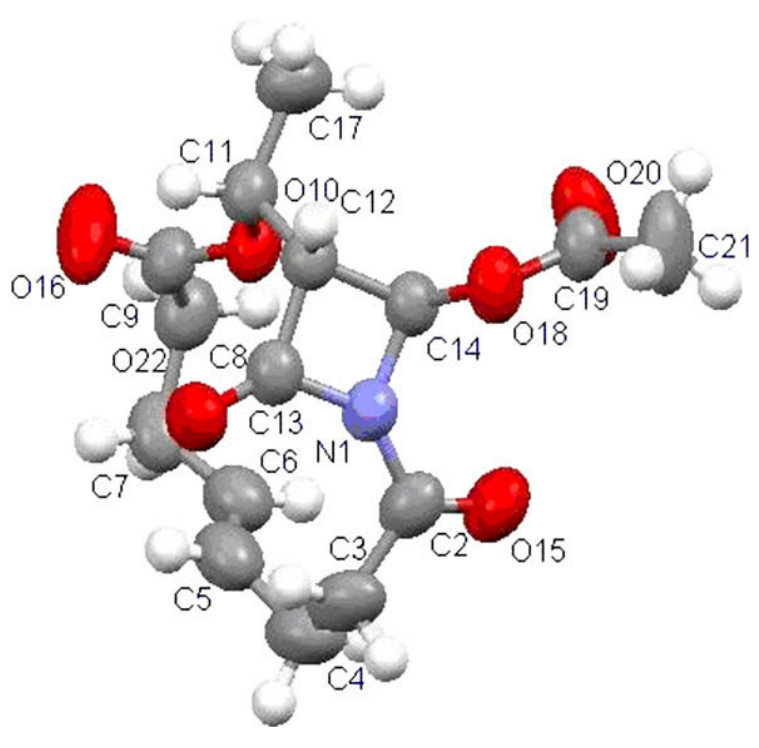

Fig. 1. X-ray structure of $\mathbf{1 1}$ (ORTEP view).

\subsection{Conformational study - heat of formation}

A lot of conformers can exist for the monocyclic molecule $\mathbf{1 0 .}$ Considering rotations around N1-C6, C4-O7 and C3-C5 bonds (see numbering of Scheme 3), and a minimum of 2 conformers per rotations, at least 8 conformers could be drawn! In the bicyclic compounds 11 and 12, rotation around C3-C5 being suppressed, a minimum of 4 conformers could be associated with each structure. This has been examined by ab initio calculations in vacuum (B3Lyp with the double basis set 6-31G(d)). Several conformers of the precursor 10, the 1,3-bridged compound $\mathbf{1 1}$ with $E$ or $Z$ configuration of the double bond, and final compound 12 have been localized on the potential energy surfaces. Three representative conformers are pictured in Scheme 4 and shown in Fig. 2 for compound 11. In conformer I, the two imide carbonyls are aligned and the 13-membered bridge unfolds up to the $\beta$-face of the fourmembered ring. A complete turning of the C3 thienamycin-like side-chain gives rise to the more stable conformer II with the large cycle covering the azetidinone $\alpha$-face. The same situation is found in the most stable conformer III, but with an antiparallel arrangement of the C2 and C6 carbonyls. For all conformers, the $E$ stereoisomer appears more stable than the $Z$ one (see Scheme 4). Conformer III ( $E$ configuration) is precisely the one rooted in the crystalline solid state of $\mathbf{1 1}$ (Figs. 1 and 2).

In solution, the coexistence of conformers for the bicycle $\mathbf{1 1}$ (or 12) was not experimentally visible by NMR spectroscopy. However, conformers were detected in the case of the monocyclic precursor 10. ${ }^{1} \mathrm{H}$ NMR spectrum recorded in $\mathrm{D}_{2} \mathrm{O}\left(25^{\circ} \mathrm{C}\right.$, addition of $\leq 5 \% d_{6^{-}}$ DMSO for complete dissolution) showed two set of signals in the 3:1 ratio: $6.55 \delta$ and $6.31 \delta$ for $\mathrm{H} 4,5.33 \delta$ and $5.21 \delta$ for $\mathrm{H} 5,3.74 \delta$ and

Table 1

X-ray data for $\mathbf{1 1}$ (for atom numbering, see Fig. 1).

\begin{tabular}{lllrll}
\hline Lengths $(\AA)$ & \multicolumn{3}{l}{ Angles and torsions $\left(^{\circ}\right)$} & \multicolumn{2}{l}{ Distances $^{\mathrm{b}}(\AA)$} \\
\hline $\mathrm{N} 1-\mathrm{C} 13$ & $1.395(4)$ & $\mathrm{C} 13-\mathrm{N} 1-\mathrm{C} 14$ & $93.5(2)$ & ${ }^{*} \mathrm{O} 22$ & +0.011 \\
$\mathrm{~N} 1-\mathrm{C} 14$ & $1.465(4)$ & $\mathrm{C} 14-\mathrm{N} 1-\mathrm{C} 2$ & $127.6(3)$ & ${ }^{*} \mathrm{C} 13$ & +0.034 \\
$\mathrm{C} 14-\mathrm{C} 12$ & $1.534(4)$ & $\mathrm{C} 13-\mathrm{N} 1-\mathrm{C} 2$ & $137.4(3)$ & ${ }^{*} \mathrm{~N} 1$ & -0.056 \\
$\mathrm{C} 13-\mathrm{C} 12$ & $1.513(5)$ & $\mathrm{C} 13-\mathrm{N} 1-\mathrm{C} 14-\mathrm{C} 12$ & $2.1(2)$ & ${ }^{*} \mathrm{C} 2$ & -0.041 \\
$\mathrm{C} 13-\mathrm{O} 22$ & $1.200(4)$ & $\mathrm{C} 2-\mathrm{N} 1-\mathrm{C} 13-\mathrm{O} 22$ & $9.9(6)$ & ${ }^{*} \mathrm{O} 15$ & +0.052 \\
$\mathrm{~N} 1-\mathrm{C} 2$ & $1.382(4)$ & C13-N1-C2-O15 & $169.1(3)$ & $\mathrm{C} 12$ & +0.225 \\
$\mathrm{C} 2-\mathrm{O} 15$ & $1.206(4)$ & C2-N1-C14-C12 & $169.9(3)$ & $\mathrm{C} 14$ & +0.172 \\
C6-C5 & $1.275(6)$ & C4-C5-C6-C7 & $173.0(4)$ & $\mathrm{h}^{\mathrm{a}}$ & 0.096 \\
\hline
\end{tabular}

a $\mathrm{N} 1$ distance, in the middle of the calculated plan from atoms linked to N1.

b Distances from the best mean plane through the atoms marked by *.
Table 2

Selected spectroscopic data.

\begin{tabular}{|c|c|c|c|}
\hline Cmpd & $\begin{array}{l}\text { IR }(C=O)^{a} \\
\left(\text { film, } \mathrm{cm}^{-1}\right)\end{array}$ & $\begin{array}{l}{ }^{1} \mathrm{H} \text { NMR }(\delta, \text { mult., } J)^{\mathrm{b}} \\
\left(500 \mathrm{MHz}, \mathrm{CDCl}_{3}, \mathrm{ppm}\right)\end{array}$ & $\begin{array}{l}{ }^{13} \mathrm{C} \text { NMR }(\mathrm{C}=\mathrm{O} \text { carbons })^{\mathrm{c}} \\
\left(125 \mathrm{MHz}, \mathrm{CDCl}_{3}, \mathrm{ppm}\right)\end{array}$ \\
\hline$\overline{10}$ & $1806,1742,1722$ & $\begin{array}{l}6.48(\mathrm{~d}, 1.6 \mathrm{~Hz}), 3.28 \\
(\mathrm{dd}, 1.6 ; 5.8 \mathrm{~Hz}), \\
5.29(\mathrm{dq}, 1.8 ; 6.4 \mathrm{~Hz})\end{array}$ & $162.2,168.8,169.2,171.7$ \\
\hline 11 & $1809,1742,1716$ & $\begin{array}{l}6.53(\mathrm{~d}, 1.6 \mathrm{~Hz}), 3.19 \\
(\mathrm{dd}, 1.6 ; 1.8 \mathrm{~Hz}), 5.58 \\
(\mathrm{dq}, 1.8 ; 6.7 \mathrm{~Hz})\end{array}$ & 163.0, 169.1, 170.7, 171.6 \\
\hline 12 & $1807,1743,1716$ & $\begin{array}{l}6.50(\mathrm{~d}, 1.5 \mathrm{~Hz}), 3.20 \\
(\mathrm{dd}, 1.5 ; 1.7 \mathrm{~Hz}), 5.53 \\
(\mathrm{dq}, 1.7 ; 6.9 \mathrm{~Hz})\end{array}$ & $163.5,169.0,171.1,171.9$ \\
\hline
\end{tabular}

a $\nu$ Values are given in the following order: $\beta$-lactam, ester and lactone, imide carbonyl functions.

b $\delta$ Values are given in the following order: $\mathrm{H} 4, \mathrm{H} 3$ and $\mathrm{H} 5$ (numbering of Scheme 3).

c $\delta$ Values are given in the following order: C2, OAc, C6, lactone (numbering of Scheme 3).

$3.38 \delta$ for $\mathrm{H} 3,2.13 \delta$ and $2.00 \delta$ for $\mathrm{MeCO}_{2}, 1.35 \delta$ and $1.29 \delta$ for MeCH5 (Fig. 3). Coalescence occurred at $72{ }^{\circ} \mathrm{C}$, giving the same pattern as the spectrum recorded in $\mathrm{CDCl}_{3}$ at $25^{\circ} \mathrm{C}$ (see Section 4).

The heat of formation of $\mathbf{1 1}$ by RCM reaction was calculated for both stereoisomers, $E$ and $Z$, by reference to the open precursor 10 minus ethylene, in the respective conformations I-III (Table 4 ). The $E$ stereoisomer was found to be more stable than the $Z$ one, in agreement with the experimental results (NMR and X-ray data). For all considered conformers, cyclisation of $\mathbf{1 0}$ into $E$-11 is favoured by about $5-7 \mathrm{kcal} \mathrm{mol}^{-1}$. The reaction is slightly endothermic in the case of conformer III in which the ester function (C3 side chain) is orientated on the outside of the $\beta$-lactam ring and the carbonyl dipoles of the imide function are opposite.

\subsection{Reactivity towards hydroxyl anion}

Basic hydrolysis of $\beta$-lactams has been intensively studied, theoretically [30-34] and experimentally [35,36]. Ring opening is a two-step process involving (i) the formation of a tetrahedral intermediate by nucleophilic addition of $\mathrm{OH}^{-}$onto the azetidinone carbonyl C2 atom, followed by (ii) the cleavage of the N1-C2 bond, this second step being the rate determining one.

Heat of formation and structure of the tetrahedral intermediates obtained by addition of $\mathrm{OH}^{-}$onto the $\beta$-lactam $\mathrm{C}=\mathrm{O}$ bond of 10-12 (conformer III) have been calculated and compared to a penam reference (Table 5). The N1-C2 bond length is indicative of the intrinsic reactivity of the studied structures: the longer bonds correspond to the more reactive azetidinones. Thus the predicted order of reactivity versus $\mathrm{OH}^{-}$is as follows: $\mathbf{1 2}>\mathbf{1 1}>\mathbf{1 0}$. However, our compounds appeared less reactive than the strained penam derivative. The computational results are interesting since the simple chemical "intuition", in this special case, could not be reliable.

Fortunately, the previous order of reactivity could be experimentally confirmed, thus establishing the validity of our computational approach. Basic hydrolysis of azetidinones 10-12 was

Table 3

Structural features of $\beta$-lactams from X-ray data.

\begin{tabular}{llllc}
\hline Cmpd & $h^{\mathrm{a}}(\AA)$ & $\begin{array}{l}\text { Bond length }^{\mathrm{b}}(\AA) \\
\text { N1-C2; C2=O }\end{array}$ & $\begin{array}{l}\text { Bond angle }^{\mathrm{b}}(\AA) \mathrm{C} 2-\mathrm{N} 1-\mathrm{C} 4 ; \\
\text { C4-N1-C6; C2-N1-C6 }\end{array}$ & $\theta^{\mathrm{c}}\left(^{\circ}\right)$ \\
\hline $\mathbf{1 1}$ & 0.096 & $1.395 ; 1.200$ & $93.5 ; 127.6 ; 137.4$ & 1.5 \\
Penam [21] & 0.38 & $1.383 ; 1.206$ & $94.26 ; 117.24 ; 125.85$ & 22.65 \\
Penem [22] & 0.42 & $1.383 ; 1.224$ & $90.55 ; 113.81 ; 126.28$ & 29.36 \\
\hline
\end{tabular}

${ }^{a} h$, Woodward's parameter (perpendicular distance of the nitrogen N1 from the plane of its three substituents).

$\mathrm{b}$ the numbering of compound $\mathbf{1 1}$ (see Scheme 3) was used for Penam and Penem representatives.

c $\theta$, Burton's parameter (torsion angle measured as $360^{\circ}$ minus the sum of the three contiguous angles around N1). 


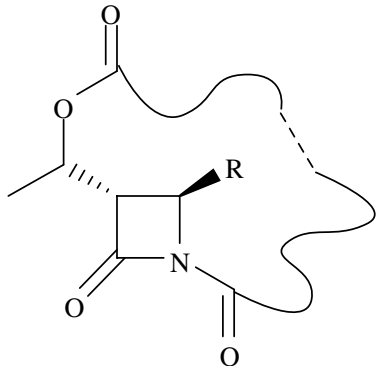

O

$$
\begin{array}{ll}
\text { E-11 } & 18.58 \\
\text { Z-11 } & 24.06
\end{array}
$$

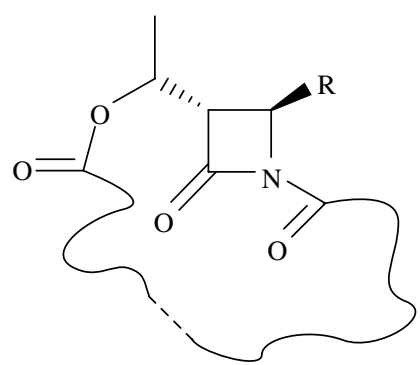

II

8.42

15.15<smiles>[Z2][C@H]1[C@@H](C(C)OC(=O)CCCCCCCCCC(=O)N2CCCCCCCC2=O)C(=O)N1C</smiles>

III

0.00

4.33

Scheme 4. Three localized conformers of 10-12. Energy differences $\left(\mathrm{kcal} \mathrm{mol}^{-1}\right)$ between conformers $\mathbf{1 1}$ are given as a function of the $\mathrm{C}=\mathrm{C}$ double bond configuration.

performed in $\mathrm{D}_{2} \mathrm{O}$ at $\mathrm{pD}=8(4 \mathrm{mM}$ solution containing $<5 \%$ $d_{6}$-DMSO, $25^{\circ} \mathrm{C}$ ) and followed by ${ }^{1} \mathrm{H}$ NMR at $500 \mathrm{MHz}$. Disappearance of the starting materials (\% SM) as a function of time (min), clearly showed that $\mathbf{1 2}$ reacts faster than $\mathbf{1 1}$, and $\mathbf{1 1}$ faster than 10 (Fig. 4). Half-life times $\left(t_{1 / 2}\right)$ are respectively about $4 \mathrm{~h}, 6 \mathrm{~h}$ and $16 \mathrm{~h}$. Azetidinone ring opening (N1-C2 cleavage) resulted in a significant shielding of the $\mathrm{H} 3$ and $\mathrm{H} 4$ protons used as internal probes. No competition with acetate (on C4), or lactone (on C5) hydrolysis could be detected, since chemical shifts of $\mathrm{CH}_{3}$ and $\mathrm{H} 5$ were almost unchanged. N1-C6 cleavage of the imide function was not observed (control of the chemical shift of $\mathrm{CH}_{2}$ next to $\mathrm{C} 6$ ), in agreement with a previous study of Page devoted to $N$-benzoyl $\beta$ lactams [37].

\subsection{Reactivity versus serine enzyme models}

A concerted mechanism of $\beta$-lactam hydrolysis, in neutral medium, could be considered as the simplest model of serineenzyme machinery [38]. In model A (Scheme 5), the nucleophile is
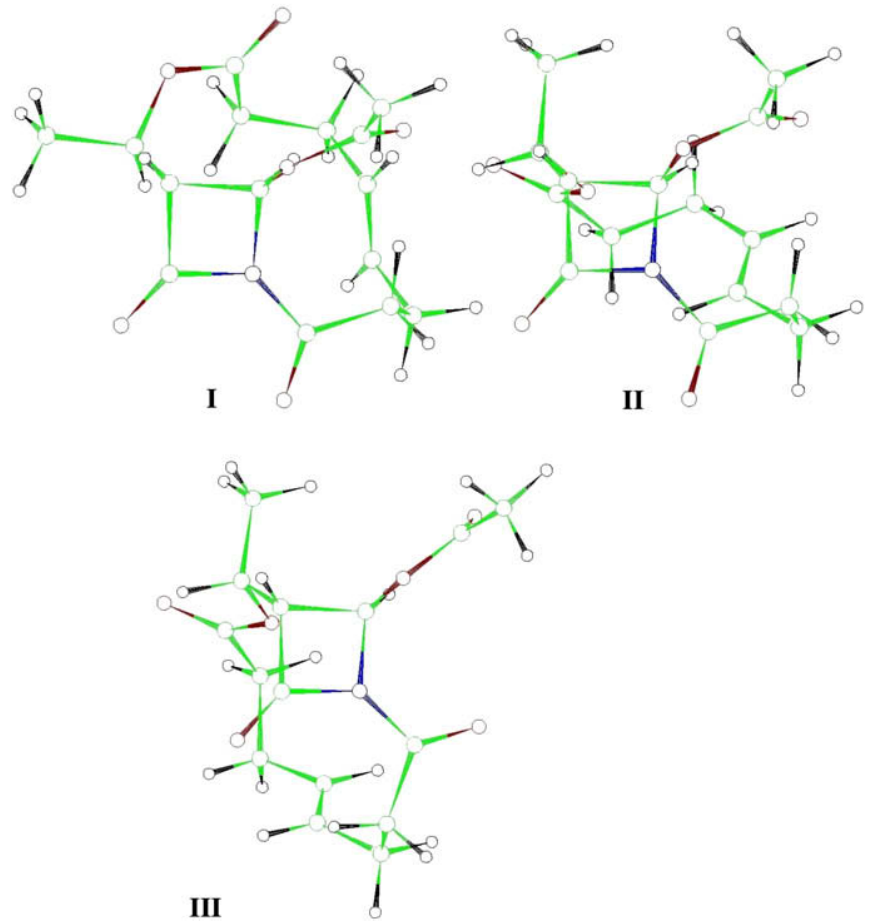

Fig. 2. Structures of calculated conformers of $\mathbf{1 1}$ ( $E$ isomer). formed by the duplex $\mathrm{H}_{2} \mathrm{O}-\mathrm{H}_{2} \mathrm{O}$ : the second water molecule acts as a proton carrier of the first water molecule to the nitrogen of the $\beta$-lactam function. Two more complex catalytic models have been used in this study, featuring two types of nucleophilic environment. In model B (Scheme 5), the catalytic machinery of the chymotrypsin family is mimicked. The triad formed by Ser-195, His-57 and Asp102 has been replaced with the triplex 2-formylamino-1-ethanol$\mathrm{H}_{2} \mathrm{O}$-imidazole. In this model, the hydrogen of the serine mimicry is transferred to the $\beta$-lactam nitrogen via a water molecule which interacts with the imidazole ring $[39,40]$. The mechanism of class-A $\beta$-lactamases has been drawn in model $C$ (Scheme 5 ). In these enzymes, the nucleophilic serine Ser-70 is surrounded by Glu-166, Lys-73 and Ser-130. In order to limit the influence of the global charge on model C, methylamine mimicking Lys-73 is neutral as this aminoacid forms a zwitterion with Glu-166. Ser-70 and Ser-130 have been replaced with 2-formylamino-1-ethanol and methanol respectively [41]. In both models $B$ and $C$, the formamide moiety mimicks the oxyanion hole stabilization.

The reactivity of $\beta$-lactams $\mathbf{1 0}-\mathbf{1 2}$ has been computed at the RHF level with the minimal basis set MINI-1'; this is imposed by the size of the analyzed systems which involve about 70 atoms [42]. For model $A$, both approaches of the azetidinone ring have been considered, on the $\alpha$-face and the $\beta$-face of the cycle. For models B and $C$, only the nucleophilic attack on the $\alpha$-face has been computed because this approach is the relevant one [43] in the active site of elastases (model B) and class A beta-lactamases (model C). Results are collected in Table 6.

The order of reactivity found for nucleophilic attack by $\left(\mathrm{H}_{2} \mathrm{O}\right)_{2}$ from the less hindered $\beta$-face (model $\mathrm{A}$, first column) was almost the same as for basic hydrolysis, i.e. $12>\mathbf{1 1}>\mathbf{1 0}$, independently of the conformer considered, with $\Delta E$ values ranging from 26.7 to $19.6 \mathrm{kcal} \mathrm{mol}^{-1}$ (conformer II) and 29.8 to 28.7 (conformer III). The 13-membered ring 1,3-bridged compounds $\mathbf{1 1}$ and $\mathbf{1 2}$ showed reactivities of similar order of magnitude as the penam compound attacked from the $\alpha$-face $\left(\Delta E=26.6 \mathrm{kcal} \mathrm{mol}^{-1}\right)$. However, this way of nucleophilic attack appeared to be highly unfavourable for the bicyclic azetidinones $\mathbf{1 1}$ and $\mathbf{1 2}$ in conformation III (model A, second column), with $\Delta E$ values of $49.1 \mathrm{kcal} \mathrm{mol}^{-1}$ and $51.3 \mathrm{kcal} \mathrm{mol}^{-1}$, respectively. Considering the chymotrypsin model (model $\mathrm{B}$, third column), the penam reference was found highly reactive $\left(\Delta E=14.6 \mathrm{kcal} \mathrm{mol}^{-1}\right)$, but not the bridged compounds 11 and 12 in the most stable conformation III $(\Delta E=39.2$ and $43.1 \mathrm{kcal} \mathrm{mol}^{-1}$ ). Due to the size of the nucleophilic triplex in the $\beta$-lactamase model (model C, fourth column), conformation III of the bicyclic azetidinones $\mathbf{1 1}$ and $\mathbf{1 2}$ was no more accessible; at the transition state, the imide carbonyl turned to give the conformation II. In this model, the penam compound appeared again more 


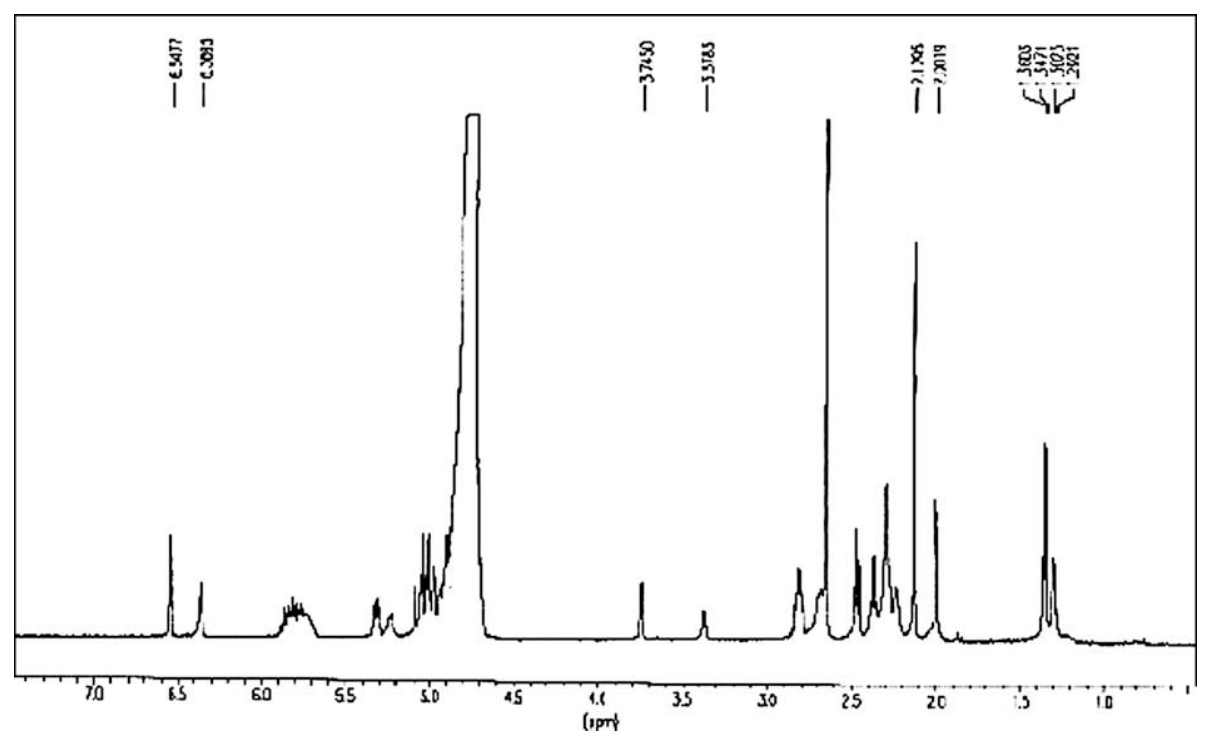

Fig. 3. ${ }^{1} \mathrm{H}$ NMR spectrum of $\mathbf{1 0}$.

reactive $\left(\Delta E=17.6 \mathrm{kcal} \mathrm{mol}^{-1}\right)$ than our large ring bridged compounds $\left(\Delta E=35.2\right.$ and $\left.50.9 \mathrm{kcal} \mathrm{mol}^{-1}\right)$. In fact, the unfolding of this ring, in the most stable conformers, hides the $\alpha$-face of the reactive four-membered ring, thus handicapping the nucleophilic attack. This is not the case for the monocyclic precursor $\mathbf{1 0}$ which is predicted to be more reactive versus serine enzymes (models $B$ and C) than both $\mathbf{1 1}$ and 12. Moreover, the conformation of the acetate substituent (on C4) could play an indirect, but probably decisive role in the transition state stabilisation. Indeed, perturbations of the $\mathrm{H}$-bonding network in the enzymic cavity were found depending on the orientation of this group. This is illustrated on Fig. 5 showing two conformers III of 10, different at the level of the OAc substituent, processed in model $C$. When the acetate carbonyl was oriented outside versus the $\beta$-lactam ring (structure b), the methanol molecule of the nucleophilic triplex moved in order to create $\mathrm{H}$-bonding interaction with this function, at the transition state. Such a phenomenon was not detected when the acetate carbonyl pointed inside versus the $\beta$-lactam ring (structure $\mathbf{a}$ ).

The theoretical study of $\mathbf{1 0 - 1 2}$ reactivity towards models of serine enzymes emphasized the huge complexity of our systems, precisely due to their conformational flexibility. It is also important to note that only the acylation step has been computed, although the complete catalytic process involves three successive steps: the

Table 4

Heat of formation of $\mathbf{1 1}$ in $\mathrm{kcal} \mathrm{mol}^{-1}$ (B3Lyp/6-31G(d)).

\begin{tabular}{llr}
\hline$\Delta E$ of $E$-isomer/Z-isomer & & \\
\hline Conformer I & 6.01 & 11.49 \\
Conformer II & 7.29 & 14.03 \\
Conformer III & 2.76 & 7.09 \\
\hline
\end{tabular}

Table 5

Tetrahedral intermediates formed by addition of $\mathrm{OH}^{-}$onto the $\beta$-lactam $\mathrm{C}=\mathrm{O}$ bond of 10, 11 and 12 in conformer III and Penam (B3Lyp/6-31G(d)).

\begin{tabular}{lll}
\hline Cmpd & N1-C2 length $(\AA)$ & $\Delta E\left(\mathrm{kcal} \mathrm{mol}^{-1}\right)$ \\
\hline $\mathbf{1 0}$ & 1.589 & 55.06 \\
$\mathbf{1 1}$ & 1.619 & 53.03 \\
$\mathbf{1 2}$ & 1.627 & 54.98 \\
Penam $^{\mathrm{a}}$ & 1.676 & 38.09 \\
\hline
\end{tabular}

a Penicillin structure without the acylamino side-chain. recognition step (formation of a Michaelis complex), the acylation step (formation of an acyl-enzyme intermediate), and the deacylation step (hydrolysis of the acyl-enzyme intermediate) [44,45].

Taking into account the limitations of our models, it seems nevertheless that the bridged $\beta$-lactams $\mathbf{1 1}$ and $\mathbf{1 2}$ could interact with serine enzymes, under selected conformations (some $\Delta E$ values are around $30 \mathrm{kcal} \mathrm{mol}^{-1}$ ), but that the monocyclic precursor $\mathbf{1 0}$ should be more active. This has been tested experimentally.

\subsection{Biochemical evaluation}

As representative enzyme of the chymotrypsin family (model B), we have considered PPE (porcine pancreatic elastase). The capacity of several $\beta$-lactam antibiotics [46,47] and monocyclic $\beta$-lactams [48-52] to inhibit elastase has been previously reported.

Compounds 10-12 were evaluated for their inhibitory effect on PPE, in a competition experiment with $N$-succinyl-L-alanyl-Lalanyl-L-alanyl- $p$-nitroanilide as substrate. The rates of PPE-catalyzed hydrolysis of the substrate were determined, in the presence of different concentrations of tested compounds (from $0.1 \mu \mathrm{M}$ to $100 \mu \mathrm{M})$, thanks to the measurement of UV-absorbance (A) at $410 \mathrm{~nm}$ (formation of $p$-nitroaniline) recorded as a function of time. The monocyclic $\beta$-lactam 10 was active at $1 \mu \mathrm{M}$ (Fig. 6), but the bicyclic $\beta$-lactams 11 and 12 were still inactive at $100 \mu \mathrm{M}$. The active

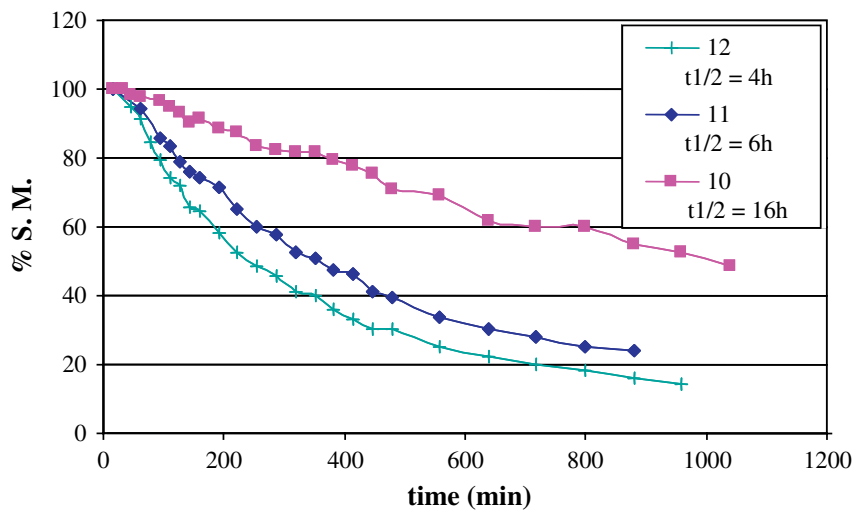

Fig. 4. Rate of hydrolysis of 10-12. 
<smiles>O=C1CCN1[TlH]O</smiles>

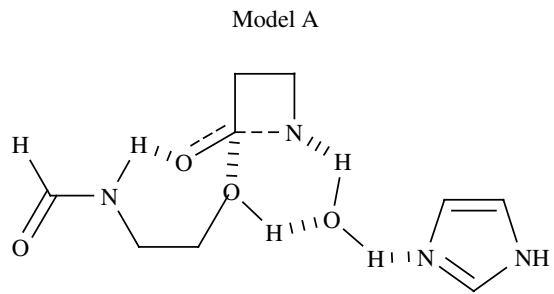

Model B

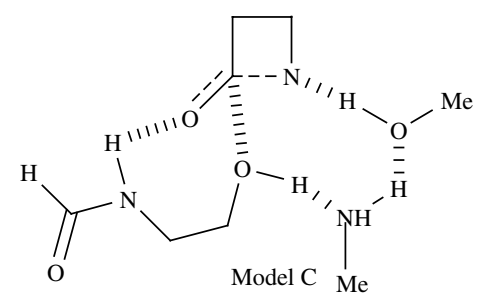

Model A: $\mathrm{H}_{2} \mathrm{O}-\mathrm{H}_{2} \mathrm{O}$ duplex (concerted chemical hydrolysis at $\mathrm{pH}$ 7)

Model B: 2-formylamino-1-ethanol $+\mathrm{H}_{2} \mathrm{O}+$ imidazole (model of elastase with Ser-195 and His-57)

Model C: 2-formylamino-1-ethanol $+\mathrm{MeNH}_{2}+\mathrm{MeOH}$ (model of PBPs with Ser-70, Lys-73 and Ser-130)

Scheme 5. Models of concerted nucleophilic attack on the $\beta$-lactam ring.

compound $\mathbf{1 0}$ behaved as a "slow substrate" or "reversible inhibitor". Indeed, after pre-incubation of PPE with 10, at different concentrations $(1,25,50,100 \mu \mathrm{M})$ and various times $(20,40$, $60 \mathrm{~min}$ ), followed by dilution with the substrate solution, the enzyme recovered slowly its activity (Fig. 7).

Our compounds were also tested against bacterial enzymes (model C), one class-A $\beta$-lactamase (TEM-1) and representative PBPs (Penicillin Binding Proteins). Indeed, our reactivity model of

Table 6

Activation energy of concerted nucleophilic attack ( $\Delta E$ in kcal mol $\left.{ }^{-1}\right)$.

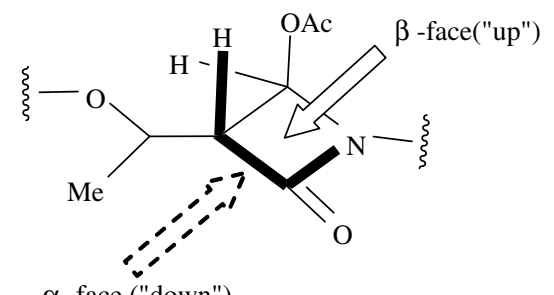

$\alpha$-face ("down")

\begin{tabular}{lllll}
\hline Cmpd (conformer) & $\begin{array}{l}\text { Model A } \\
(\beta \text {-face })^{\mathrm{a}}\end{array}$ & $\begin{array}{l}\text { Model A } \\
(\alpha \text {-face })^{\mathrm{a}}\end{array}$ & $\begin{array}{l}\text { Model B } \\
(\alpha \text {-face })^{\mathrm{a}}\end{array}$ & $\begin{array}{l}\text { Model C } \\
(\alpha \text {-face })^{\mathrm{a}}\end{array}$ \\
\hline $\mathbf{1 0}$ (I) & - & - & 28.91 & 37.41 \\
$\mathbf{1 0}$ (II) & 26.72 & 33.10 & - & - \\
$\mathbf{1 0}$ (III) & 29.69 & 41.30 & 30.81 & 32.75 \\
$\mathbf{1 1}$ (I) & - & - & 26.47 & 38.29 \\
$\mathbf{1 1}$ (II) & 24.46 & 37.22 & - & 35.17 \\
$\mathbf{1 1}$ (III) & 29.83 & 49.07 & 39.22 & - \\
$\mathbf{1 2}$ (I) & - & - & 30.78 & 36.28 \\
$\mathbf{1 2}$ (II) & 19.61 & 34.84 & - & 50.89 \\
$\mathbf{1 2}$ (III) & 28.70 & 51.33 & 43.16 & - \\
Penam & $/$ & 26.56 & 14.62 & 17.59 \\
\hline
\end{tabular}

a Definition of nucleophilic attack from $\alpha$-face or $\beta$-face.

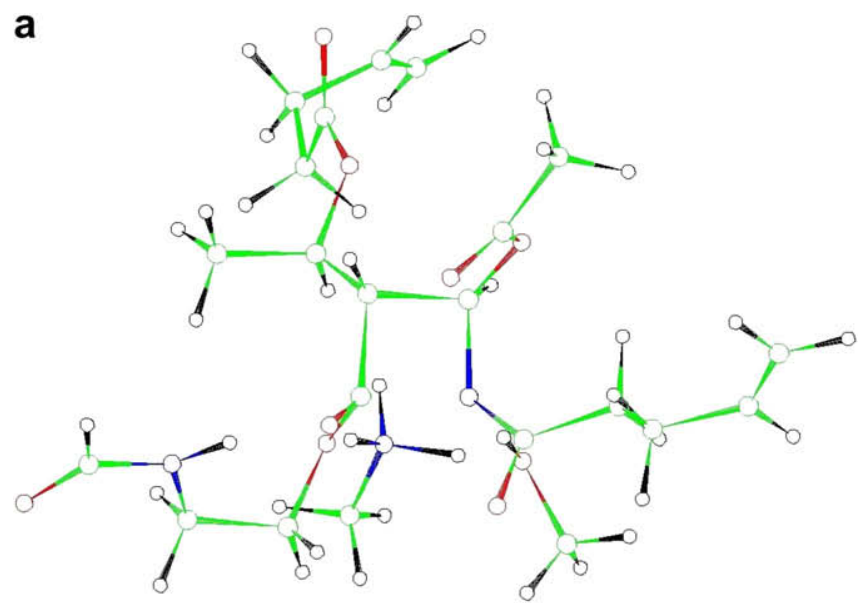

b

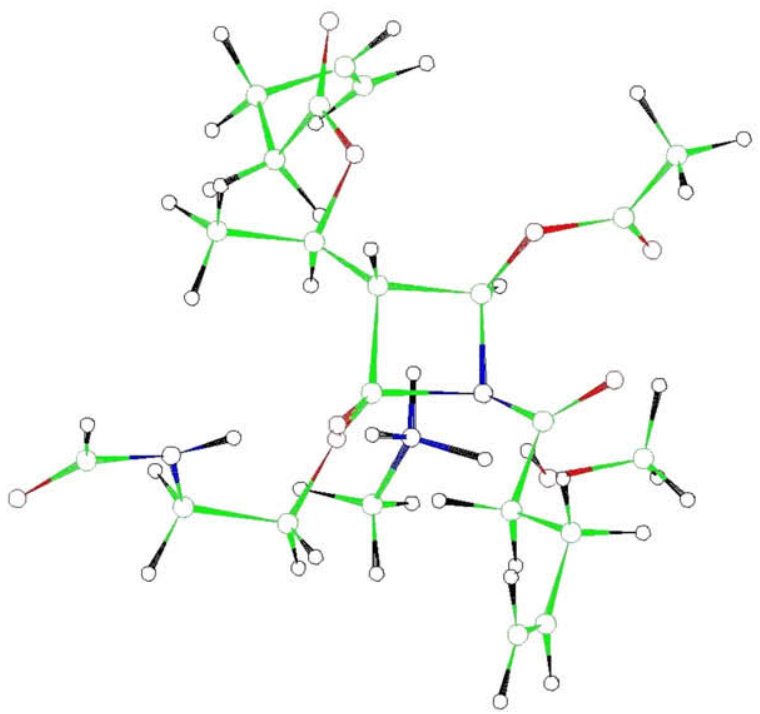

Fig. 5. Processing of $\mathbf{1 0}$ in model C; two conformers III, $\mathbf{a}$ and $\mathbf{b}$.

serine $\beta$-lactamases mimicks the entities involved during the acylation mechanism, namely Ser-70, Lys-73 and Ser-130. These amino acids are also present in the active site of D,D-peptidases, as proven by crystallographic studies of Actinomadura R39 [53] and Streptomyces K15 [54].

The potential inhibition of TEM- 1 by $\beta$-lactams 10-12 was evaluated as above, in competition experiments with a chromogenic substrate (nitrocefine), but none of the compounds was found active at $100 \mu \mathrm{M}$. R39 is a model enzyme of low molecular weight D,Dpeptidases [53]. The other considered PBPs are high molecular weight

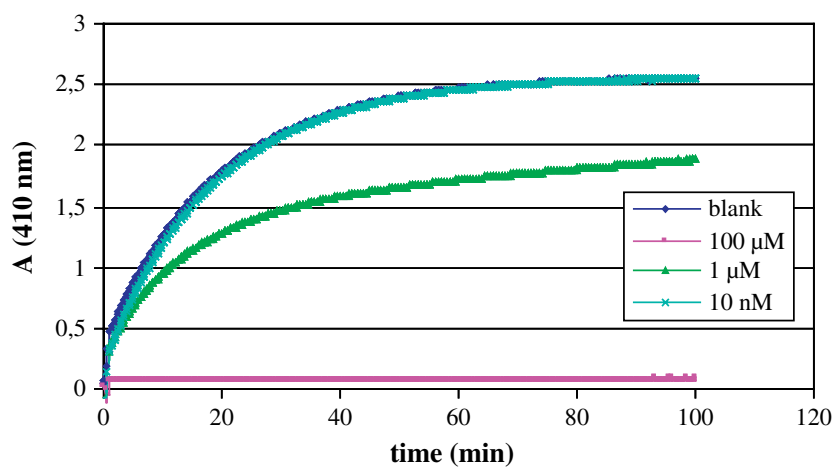

Fig. 6. Inhibition of PPE by azetidinone $\mathbf{1 0}$. 


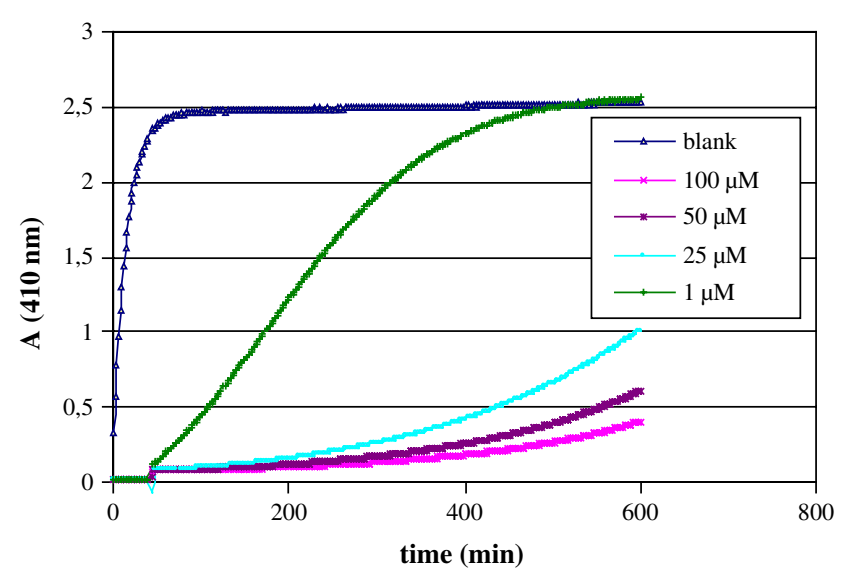

Fig. 7. Reversibility of PPE inhibition by $\mathbf{1 0}$ (60 min incubation).

enzymes responsible for bacterial resistance to $\beta$-lactam antibiotics: [55-57] $\mathrm{PBP}_{2 \mathrm{a}}$ from Staphylococcus aureus ATCC433000 [58,59], $\mathrm{PBP}_{5 \mathrm{fm}}$ from Enterococcus faecium [60], and $\mathrm{PBP}_{2 \mathrm{x}}$ from Streptococcus pneumoniae 5204 [61-63]. The peptidases $(0.8$ or $2.5 \mu \mathrm{M})$ and the azetidinones 10-12 $(100 \mu \mathrm{M})$ were incubated during $16 \mathrm{~h}$, then fluorescent ampicillin $(25 \mu \mathrm{M})$ was added. After $45 \mathrm{~min}$, the proteins were denaturated, and the fluorescence intensity (resulting from the covalent protein-ampicillin complexes) was measured. In this protocol, the tested compounds were supposed to be able of acylating the PBPs, and the residual activities of the proteins were thus determined. Results of Table 7 are expressed in percentages of initial activity. Thus low \% values indicate very active compounds. Benzylpenicillin (Pen G), used as positive control, showed values of about 5-10\%. The monocyclic azetidinone $\mathbf{1 0}$ was highly active against R39, moderately active against $\mathrm{PBP}_{2 \mathrm{a}}$, and weakly active against $\mathrm{PBP}_{5 \mathrm{fm}}$. The bicyclic azetidinones $\mathbf{1 1}$ and $\mathbf{1 2}$ were weakly active only against $\mathrm{PBP}_{2 \mathrm{a}}$. None of the compounds inhibited $\mathrm{PBP}_{2 \mathrm{x}}$. In opposition to the chemical reactivity, the biochemical tests pointed out azetidinone $\mathbf{1 0}$ as the most active compound. Nevertheless promising activities of azetidinones 11 and 12 were recruited versus $\mathrm{PBP}_{2 \mathrm{a}}$, a clinically relevant target of MRSA strains.

\section{Conclusions}

We have explored a non-traditional approach for designing reactive $\beta$-lactams, and possibly new antibacterial agents. Instead of increasing the angular strain and the $\mathrm{N} 1$ pyramidality ("twisted amide") in the azetidinone ring of 1,4 -fused bi- $[64,65]$ or tricyclic systems [66], we considered flexible 1,3-bridged bicyclic systems featuring a "planar amide" and a large ring susceptible to generate a lot of conformers. Such azetidinones, endowed with a thienamycin-like side-chain at C3 and the related stereochemistry at C3-C5, are readily accessible via a convergent RCM strategy, as illustrated by the synthesis of the 13-membered bicycles $E$ - $\mathbf{1 1}$ and $\mathbf{1 2}$ from the commercial chiron $\mathbf{7}$, precursor of $\mathbf{1 0}$. The experimental structural data (IR and NMR spectroscopic analyses and X-ray diffraction) confirmed that $\beta$-lactams 10-12 are well planar amides. Theoretical analysis of our novel systems revealed that their reactivity towards

Table 7

Inhibition of bacterial enzymes. Results are given as percentages of initial activity.

\begin{tabular}{lclcc}
\hline Cmpd $^{\mathrm{a}}$ & $\mathrm{R} 39(0.8 \mu \mathrm{M})$ & $\mathrm{PBP}_{2 \mathrm{a}}(2.5 \mu \mathrm{M})$ & $\mathrm{PBP}_{5 \mathrm{fm}}(2.5 \mu \mathrm{M})$ & $\mathrm{PBP}_{2 \mathrm{x}}(0.8 \mu \mathrm{M})$ \\
\hline $\mathbf{1 0}$ & $14 \pm 2$ & $66 \pm 14$ & $84 \pm 12$ & $93 \pm 6$ \\
$\mathbf{1 1}$ & $96 \pm 4$ & $86 \pm 8$ & $104 \pm 4$ & $116 \pm 5$ \\
$\mathbf{1 2}$ & $113 \pm 18$ & $94 \pm 3$ & $113 \pm 11$ & $99 \pm 4$ \\
Pen G & $\mathrm{nd}^{\mathrm{b}}$ & $13 \pm 3$ & $10 \pm 3$ & $<5$ \\
\hline
\end{tabular}

a Compounds were tested at $100 \mu \mathrm{M}$.

b Not determined. nucleophiles $\left(\mathrm{OH}^{-}, \mathrm{H}_{2} \mathrm{O}-\mathrm{H}_{2} \mathrm{O}\right)$ and serine enzymes (models $\mathrm{B}$ and $\mathrm{C}$ ) indeed depends significantly on the considered conformers.

The chemical reactivity of compounds $\mathbf{1 0}-\mathbf{1 2}$ could be correctly predicted by $a b$ initio calculations, regarding their half-live times in phosphate buffer. Both bicyclic azetidinones $\mathbf{1 1}$ and $\mathbf{1 2}$ are more reactive than their monocyclic precursor 10, probably because some angular strain still operates in the 13-membered bridged series. The enhanced reactivity of $\mathbf{1 2}$ (saturated large cycle) versus 11 ( $\mathrm{C}=\mathrm{C}$ double bond with $E$-configuration in the large ring) can result from torsion (or eclipse) strains and transannular interactions which become more important when carbon atoms with $\mathrm{sp}^{2}$ geometry are transformed into the $\mathrm{sp}^{3}$ one.

The reactivity of azetidinones $\mathbf{1 0}-\mathbf{1 2}$ versus serine enzymes appeared hardly predictable by theoretical tools. Nevertheless, the crucial role of geometrical factors ("up" or "down" nucleophilic attack of the $\beta$-lactam carbonyl) has been pointed out. Consequently, the monocyclic precursor $\mathbf{1 0}$ seems to be more capable of fitting within an enzymic cavity than the bicycles $\mathbf{1 1}$ and $\mathbf{1 2}$. Experimentally, we found that $\mathbf{1 0}$ behaves as a good inhibitor of a mammalian elastase. The slow (and partial) reversibility of this inhibition is reminiscent of the mechanism of action of clavulanic acid and 6 - $\beta$-bromopenicillanic acid versus class A $\beta$-lactamases (such inhibitors are called "passive covalent inhibitors") [67,68]. Also, 10 was an excellent inhibitor of the bacterial D,D-peptidase R39. This result abolishes an old dogma in the field of penicillintype antibiotics, i.e. the need of a carboxylic function on the substrate/inhibitor for promoting a good interaction with PBP enzymes. Yet, the most stimulating biochemical result was the discovery of novel inhibitors of $\mathrm{PBP}_{2 \mathrm{a}}$ featuring non-traditional structures: their activities are moderate (10) to modest (11) and weak (12), but well measurable.

The emergence of penicillin-resistant bacterial strains and the recent dramatic increase of those strains, all over the world, represent a major concern in medicine. Particularly, the prevalence of MRSA (methicillin-resistant Staphylococcus aureus) in hospitals has stimulated the development of more potent carbapenems (ME 1036 [64]) and cephalosporins (PPI 0903M [65]), characterized by very bulky substituents on the bicyclic skeletons. The lethal action of such antibiotics is due to their high affinity for $\mathrm{PBP}_{2 a}$. The development of large ring 1,3-bridged 2-azetidinones, structurally related to the carbapenem family (2-hydroxyethyl side chain on C3 and thienamycin stereochemistry) and the cephalosporin family (acylamino side chain on C3 and penicillin stereochemistry), is currently continued in our laboratory.

The present preliminary results pave the route of a possible alternative strategy for the discovery of novel 'hits' towards resistant infections.

\section{Experimental section}

\subsection{General}

Manipulations were performed under an argon atmosphere in flame-dried glassware. Reagents were used as-received and solvents were dried by standard procedures. TLC analyses were performed on aluminium plates coated with silica gel $60 \mathrm{~F}_{254}$ (Merck) and visualized with UV $(254 \mathrm{~nm})$ and $\mathrm{KMNO}_{4}$ solution. Melting points were measured on Electrothermal apparatus calibrated with benzoic acid (uncorrected m.p.).Column chromatographies were performed on silica gel Merck $60(40-60 \mu \mathrm{m})$. NMR spectra were recorded on a Bruker Avance 500 spectrometer at $500 \mathrm{MHz}\left({ }^{1} \mathrm{H}\right)$ and $175 \mathrm{MHz}\left({ }^{13} \mathrm{C}\right)$ in $\mathrm{CDCl}_{3}$ with TMS as an internal standard. IR spectra were recorded on Shimadzu FTIR-8400S spectrometer; compounds were deposited on $\mathrm{NaCl}$ plates as a thin film by evaporation from $\mathrm{CH}_{2} \mathrm{Cl}_{2}$ solution. High Resolution MS were obtained in the Mass Spectrometry Service of the University of Mons-Hainaut, Belgium. 


\subsection{Synthesis}

4.2.1. 1-(Pent-4-enoyl)-(3R,4R)-3-[1(R)-(tert-butyldimethylsilyloxy)ethyl]-4-(acetoxy)-azetidin-2-one (8)

To a stirred solution of acetoxy-azetidinone $7(500 \mathrm{mg}$ $1.74 \mathrm{mmol})$ in dry $\mathrm{CH}_{2} \mathrm{Cl}_{2}(15 \mathrm{~mL})$ were added pyridine $(0.28 \mathrm{~mL}$, $3.48 \mathrm{mmol}$ ) and 4 -pentenoyl chloride $(0.38 \mathrm{~mL}, 3.48 \mathrm{mmol})$. The solution was heated at $35^{\circ} \mathrm{C}$ under an argon atmosphere for $65 \mathrm{~h}$. Then the reaction mixture was diluted with $\mathrm{CH}_{2} \mathrm{Cl}_{2}(50 \mathrm{~mL})$ and successively washed with a $3.3 \mathrm{M} \mathrm{HCl}$ solution $(50 \mathrm{~mL})$, a saturated $\mathrm{NaHCO}_{3}$ solution $(50 \mathrm{~mL})$ and brine $(50 \mathrm{~mL})$. The organic phase was dried over $\mathrm{MgSO}_{4}$ and concentrated under vacuum. The residue was purified by flash chromatography (cyclohexane/EtOAc 10:1) to furnish imide 8 as a pale yellow oil ( $515 \mathrm{mg}, 80 \%) . R_{\mathrm{f}}=0.57$ (cyclohexane/EtOAc 5:2); ${ }^{1} \mathrm{H}$ NMR: $\delta=6.58(\mathrm{~d}, J=1.6 \mathrm{~Hz}, 1 \mathrm{H} ; \mathrm{H} 4)$, 5.82 (ddt, $J=6.5,10.5,17.2 \mathrm{~Hz}, 1 \mathrm{H} ; \mathrm{CH}=\mathrm{CH}_{2}$ ), 5.08 (dd, $J=1.6$, $17.2 \mathrm{~Hz}, 1 \mathrm{H} ; \mathrm{CH}=\mathrm{CH}_{2}$ ), 5.01 (dd, $J=1.6,10.5 \mathrm{~Hz}, 1 \mathrm{H} ; \mathrm{CH}=\mathrm{CH}_{2}$ ), 4.29 (qd, $J=2.5,6.7 \mathrm{~Hz}, 1 \mathrm{H} ; \mathrm{H} 5), 3.12$ (dd, $J=1.6,2.5 \mathrm{~Hz}, 1 \mathrm{H} ; \mathrm{H} 3$ ), 2.81 (td, $\left.J=7.6,16.9 \mathrm{~Hz}, 1 \mathrm{H} ; \mathrm{CO}-\mathrm{CH}_{2}\right), 2.74(\mathrm{td}, J=7.6,16.9 \mathrm{~Hz}, 1 \mathrm{H} ; \mathrm{CO}-$ $\left.\mathrm{CH}_{2}\right), 2.40\left(\mathrm{td}, J=6.5,7.6 \mathrm{~Hz}, 2 \mathrm{H} ; \mathrm{CH}_{2}-\mathrm{C}=\mathrm{C}\right), 2.10\left(\mathrm{~s}, 3 \mathrm{H} ; \mathrm{COCH}_{3}\right)$, $1.31\left(\mathrm{~d}, J=6.7 \mathrm{~Hz}, 3 \mathrm{H} ; \mathrm{CH}_{3}-\mathrm{CH}-\mathrm{O}\right), 0.82$ (s, 9H; SitBu), 0.03 (s, 3H; $\left.\mathrm{SiCH}_{3}\right), 0.07$ (s, 3H; $\left.\mathrm{SiCH}_{3}\right) ;{ }^{13} \mathrm{C}$ NMR: $\delta=169.1$ (C6), 168.9 (OCOMe), $164.4(\mathrm{C} 2), 136.2(\mathrm{CH}=\mathrm{C}), 115.8\left(\mathrm{C}=\mathrm{CH}_{2}\right), 74.1(\mathrm{C} 4), 65.0(\mathrm{C} 3), 64.1$ (C5), $35.6\left(\mathrm{COCH}_{2}\right), 27.4\left(\mathrm{CH}_{2} \mathrm{C}=\right), 25.5\left(\mathrm{C}\left(\mathrm{CH}_{3}\right)_{3}\right), 21.7\left(\mathrm{CH}_{3} \mathrm{CH}-\mathrm{O}\right)$,

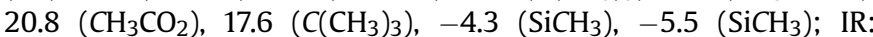
$\nu=1808,1759,1721,1642,1306^{1}$; HR-ESI-TOF-Mass (positivemode): $\mathrm{m} / z$ calcd for $\mathrm{C}_{18} \mathrm{H}_{31} \mathrm{NO}_{5} \mathrm{Si}+\mathrm{Na}$ : 392.1869; found: 392.1863 .

4.2.2. 1-(Pent-4-enoyl)-(3R,4R)-3-[1(R)-hydroxyethyl]-4(acetoxy)-azetidin-2-one $(\mathbf{9})$

$\beta$-Lactam $8(850 \mathrm{mg}, 2.3 \mathrm{mmol})$ dissolved in $\mathrm{CH}_{3} \mathrm{CN}(100 \mathrm{~mL})$ was treated with $17 \mathrm{M} \mathrm{AcOH}(0.95 \mathrm{~mL}, 16.1 \mathrm{mmol})$ and $12 \mathrm{M} \mathrm{HCl}$ $\left(0.96 \mathrm{~mL}, 11.5 \mathrm{mmol}\right.$ ) at $0{ }^{\circ} \mathrm{C}$ for $3 \mathrm{~h}$. The solvent was removed under vacuum and the residue diluted with EtOAc $(50 \mathrm{~mL})$. The organic phase was washed with a $10 \% \mathrm{Na}_{2} \mathrm{CO}_{3}$ solution and brine $(2 \times 50 \mathrm{~mL})$, then dried over $\mathrm{MgSO}_{4}$ and concentrated. The crude alcohol was purified by flash chromatography (cyclohexane/EtOAc 5:3) to yield 9 as a pale yellow oil (490 mg, 83\%). Compound 9 can also be used without purification in the next step. $R_{\mathrm{f}}=0.40$ (cyclohexane/EtOAc 5:3); ${ }^{1} \mathrm{H}$ NMR: $\delta=6.33(\mathrm{~d}, J=1.4 \mathrm{~Hz}, 1 \mathrm{H} ; \mathrm{H} 4)$, 5.72 (ddt, $J=6.8,10.3,17.1 \mathrm{~Hz}, 1 \mathrm{H} ; \mathrm{CH}=\mathrm{CH}_{2}$ ), 4.98 (dd, $J=1.5$, $\left.17.1 \mathrm{~Hz}, 1 \mathrm{H} ; \mathrm{CH}=\mathrm{CH}_{2}\right), 4.91$ (dd, $\left.J=1.5,10.3 \mathrm{~Hz}, 1 \mathrm{H} ; \mathrm{CH}=\mathrm{CH}_{2}\right), 4.13$ (qd, $J=5.4,6.4 \mathrm{~Hz}, 1 \mathrm{H} ; \mathrm{H} 5), 3.30(\mathrm{br} \mathrm{s}, 1 \mathrm{H} ; \mathrm{OH}), 3.08$ (dd, $J=1.4$, $5.4 \mathrm{~Hz}, 1 \mathrm{H}$; H3), $2.70\left(\mathrm{~m}, 2 \mathrm{H}\right.$; $\left.\mathrm{CO}-\mathrm{CH}_{2}\right), 2.30(\mathrm{td}, J=6.8,7.4 \mathrm{~Hz}, 2 \mathrm{H}$; $\left.\mathrm{CH}_{2}-\mathrm{C}=\mathrm{C}\right), 2.02\left(\mathrm{~s}, 3 \mathrm{H} ; \mathrm{COCH}_{3}\right), 1.24\left(\mathrm{~d}, J=6.4 \mathrm{~Hz}, 3 \mathrm{H} ; \mathrm{CH}_{3}-\mathrm{CH}-\mathrm{O}\right)$; ${ }^{13} \mathrm{C}$ NMR: $\delta=169.9(\mathrm{C} 6), 169.5\left(\mathrm{OCOCH}_{3}\right), 163.3(\mathrm{C} 2), 136.0(\mathrm{CH}=\mathrm{C})$, $115.8\left(\mathrm{C}=\mathrm{CH}_{2}\right), 75.2(\mathrm{C} 4), 64.9(\mathrm{C} 3), 63.8(\mathrm{C} 5), 35.6\left(\mathrm{COCH}_{2}\right), 27.4$ $\left(\mathrm{CH}_{2}-\mathrm{C}=\mathrm{C}\right), 20.9\left(\mathrm{CH}_{3} \mathrm{CHO}\right), 20.7\left(\mathrm{CH}_{3} \mathrm{CO}_{2}\right) ; \mathrm{IR}: \nu=3501,1805,1755$, $1718,1641,1311 \mathrm{~cm}^{-1}$; HR-ESI-TOF-Mass (positive-mode): $\mathrm{m} / \mathrm{z}$ calcd for $\mathrm{C}_{12} \mathrm{H}_{17} \mathrm{NO}_{5}+\mathrm{Na}$ : 278.1004; found: 278.0992 .

\subsubsection{1-(Pent-4-enoyl)-(3R,4R)-3-[1(R)-(pent-4-enoyloxy)-ethyl]-} 4-(acetoxy)-azetidin-2-one (10)

To a stirred solution of $\beta$-lactam $9(800 \mathrm{mg}, 3.14 \mathrm{mmol})$ in dry $\mathrm{CH}_{2} \mathrm{Cl}_{2}(20 \mathrm{~mL})$ were added pyridine $(0.38 \mathrm{~mL}, 6.28 \mathrm{mmol})$ and $4-$ pentenoyl chloride $(0.69 \mathrm{~mL}, 6.28 \mathrm{mmol})$. The reaction was performed at room temperature under an argon atmosphere for $3 \mathrm{~h}$. The mixture was diluted with $\mathrm{CH}_{2} \mathrm{Cl}_{2}(50 \mathrm{~mL})$ and successively washed with a $3.3 \mathrm{M} \mathrm{HCl}$ solution $(50 \mathrm{~mL})$, a saturated $\mathrm{NaHCO}_{3}$ solution $(50 \mathrm{~mL})$ and brine $(50 \mathrm{~mL})$. The organic phase was dried over $\mathrm{MgSO}_{4}$ and concentrated. The residue was purified by flash chromatography (cyclohexane/EtOAc $5: 2$ ) to provide $\mathbf{1 0}$ as a pale yellow oil (950 mg, 90\%). $R_{\mathrm{f}}=0.56$ (cyclohexane/EtOAc $\left.5: 2\right) ;{ }^{1} \mathrm{H}$ NMR: $\delta=6.48(\mathrm{~d}, J=1.6 \mathrm{~Hz}, 1 \mathrm{H} ; \mathrm{H} 4), 5.82(\mathrm{ddt}, J=6.4,10.3,17.0 \mathrm{~Hz}$, $1 \mathrm{H} ; \mathrm{CH}=\mathrm{CH}_{2}$ ), 5.78 (ddt, $\left.J=6.4,10.3,17.0 \mathrm{~Hz}, 1 \mathrm{H} ; \mathrm{CH}=\mathrm{CH}_{2}\right), 5.29$ (qd, $J=5.8,6.4 \mathrm{~Hz}, 1 \mathrm{H} ; \mathrm{H} 5), 5.08\left(\mathrm{dd}, J=1.6,17.0 \mathrm{~Hz}, 1 \mathrm{H} ; \mathrm{CH}=\mathrm{CH}_{2}\right.$ ), $5.05\left(\mathrm{dd}, J=1.6,17.0 \mathrm{~Hz}, 1 \mathrm{H} ; \mathrm{CH}=\mathrm{CH}_{2}\right), 5.02(\mathrm{dd}, J=1.6,10.3 \mathrm{~Hz}, 1 \mathrm{H}$; $\left.\mathrm{CH}=\mathrm{CH}_{2}\right), 5.00\left(\mathrm{dd}, J=1.6,10.3 \mathrm{~Hz}, 1 \mathrm{H} ; \mathrm{CH}=\mathrm{CH}_{2}\right), 3.28(\mathrm{dd}, J=1.6$, $5.8 \mathrm{~Hz}, 1 \mathrm{H} ; \mathrm{H} 3), 2.80\left(\mathrm{~m}, 2 \mathrm{H} ; \mathrm{NCOCH}_{2}\right), 2.40\left(\mathrm{~m}, 4 \mathrm{H} ; \mathrm{OCOCH}_{2}\right.$ and $\left.\mathrm{CH}_{2} \mathrm{C}=\mathrm{C}\right), 2.34\left(\mathrm{~m}, 2 \mathrm{H} ; \mathrm{CH}_{2} \mathrm{C}=\mathrm{C}\right), 2.11\left(\mathrm{~s}, 3 \mathrm{H} ; \mathrm{OCOCH}_{3}\right), 1.39$ (d, $J=6.4 \mathrm{~Hz}, 3 \mathrm{H}$; $\left.\mathrm{CH}_{3}-\mathrm{CHO}\right) ;{ }^{13} \mathrm{C}$ NMR: $\delta=171.7\left(\mathrm{OCOCH}_{2}\right), 169.2(\mathrm{C} 6)$, $168.8\left(\mathrm{OCOCH}_{3}\right), 162.2(\mathrm{C} 2), 136.2\left(\mathrm{CH}=\mathrm{CH}_{2}\right), 135.9\left(\mathrm{CH}=\mathrm{CH}_{2}\right)$, $115.9\left(\mathrm{CH}=\mathrm{CH}_{2}\right), 115.6\left(\mathrm{CH}=\mathrm{CH}_{2}\right), 74.5(\mathrm{C} 4), 65.6(\mathrm{C} 5), 62.5(\mathrm{C} 3)$, $35.7\left(\mathrm{NCO}-\mathrm{CH}_{2}\right), 33.3\left(\mathrm{OCOCH}_{2}\right), 28.6\left(\mathrm{CH}_{2} \mathrm{C}=\mathrm{C}\right), 27.4\left(\mathrm{CH}_{2} \mathrm{C}=\mathrm{C}\right)$, $20.6\left(\mathrm{OCOCH}_{3}\right), 18.1\left(\mathrm{CH}_{3} \mathrm{CHO}\right)$; IR: $\nu=1806,1742,1722,1642$, $1313 \mathrm{~cm}^{-1}$; HR-ESI-TOF-Mass (positive-mode): $\mathrm{m} / \mathrm{z}$ calcd for $\mathrm{C}_{17} \mathrm{H}_{23} \mathrm{NO}_{6}+\mathrm{Na}$ : 360.1423; found: 360.1412 .

\subsection{4. (E,11R,12R,14R)-14-(Acetoxy)-11-(methyl)-2, 9, 13-trioxo-10-} oxa-1-aza-bicyclo-[10.1.1]-tetradec-5-ene (11)

Grubbs catalyst of second generation was used (Scheme 6).

To a stirred solution of $\beta$-lactam $10(355 \mathrm{mg}, 1.05 \mathrm{mmol})$ in dry $\mathrm{CH}_{2} \mathrm{Cl}_{2}(200 \mathrm{~mL},[5 \mathrm{mM}])$ was added Grubbs catalyst $(44.7 \mathrm{mg}$, $0.053 \mathrm{mmol}$ ). The reaction was performed at room temperature under an argon atmosphere for $5 \mathrm{~h}$. Then the solvent was removed and the residue purified by flash chromatography (cyclohexane/ EtOAc 5:2) to provide $\mathbf{1 1}$ as a white solid (268 mg, 83\%). $R_{\mathrm{f}}=0.54$ (cyclohexane/EtOAc 5:3); m.p. $=117.8^{\circ} \mathrm{C} ;{ }^{1} \mathrm{H}$ NMR: $\delta=6.53$ (d, $J=1.6 \mathrm{~Hz}, 1 \mathrm{H}$; H4), 5.58 (qd, $J=1.8,6.7 \mathrm{~Hz}, 1 \mathrm{H} ; \mathrm{H} 5), 5.46(\mathrm{~m}, 1 \mathrm{H}$; $\mathrm{CH}=\mathrm{CH}), 5.40(\mathrm{~m}, 1 \mathrm{H} ; \mathrm{CH}=\mathrm{CH}), 3.27(\mathrm{~m}, 1 \mathrm{H} ; \mathrm{NCO}-\mathrm{CH}), 3.19(\mathrm{dd}$, $J=1.6,1.8 \mathrm{~Hz}, 1 \mathrm{H} ; \mathrm{H} 3), 2.46(\mathrm{~m}, 1 \mathrm{H} ; \mathrm{OCO}-\mathrm{CH}), 2.40(\mathrm{~m}, 3 \mathrm{H} ; \mathrm{NCO}-$ $\left.\mathrm{CH}+\mathrm{CH}_{2} \mathrm{C}=\mathrm{C}\right), 2.30\left(\mathrm{~m}, 3 \mathrm{H} ; \mathrm{OCO}-\mathrm{CH}+\mathrm{C}=\mathrm{C}-\mathrm{CH}_{2}\right), 2.13(\mathrm{~s}, 3 \mathrm{H}$; $\left.\mathrm{OCOCH}_{3}\right), 1.40\left(\mathrm{~d}, J=6.7 \mathrm{~Hz}, 3 \mathrm{H} ; \mathrm{CH}_{3} \mathrm{CHO}\right) ;{ }^{13} \mathrm{C}$ NMR: $\delta=171.6$ $\left(\mathrm{OCOCH}_{2}\right), 170.7\left(\mathrm{NCOCH}_{2}\right), 169.1\left(\mathrm{OCOCH}_{3}\right), 163.0(\mathrm{C} 2), 130.4$ $(\mathrm{CH}=\mathrm{C}), 128.3(\mathrm{C}=\mathrm{CH}), 74.1(\mathrm{C} 4), 64.9(\mathrm{C} 5), 62.7(\mathrm{C} 3), 34.7$ $\left(\mathrm{NCOCH}_{2}\right), 33.7\left(\mathrm{OCOCH}_{2}\right), 30.3\left(\mathrm{CH}_{2} \mathrm{C}=\mathrm{C}\right), 28.2\left(\mathrm{C}=\mathrm{C}-\mathrm{CH}_{2}\right), 20.8$ $\left(\mathrm{OCOCH}_{3}\right), 18.4\left(\mathrm{CH}_{3} \mathrm{CO}\right)$; IR: $\nu=1809,1742,1716 \mathrm{~cm}^{-1}$; HR-ESI-TOFMass (positive-mode): $\mathrm{m} / z$ calcd for $\mathrm{C}_{15} \mathrm{H}_{19} \mathrm{NO}_{6}+\mathrm{Na}$ : 332.1110; found: 332.1101 .

\subsection{5. (11R,12R,14R)-14-(Acetoxy)-11-(methyl)-2, 9, 13-trioxo-10- oxa-1-aza-bicyclo-[10.1.1]-tetradecane (12)}

Precursor 11 (266 mg, $0.87 \mathrm{mmol})$ dissolved in EtOAc $(15 \mathrm{~mL})$ was placed under $\mathrm{H}_{2}$ atmosphere (1 atm) at room temperature in the presence of Pd catalyst ( $20 \mathrm{mg}, 10 \%$ on C) for $17 \mathrm{~h}$. Filtration and concentration under vacuum furnished $\mathbf{1 2}$ as a white solid $(270 \mathrm{mg}$, $100 \%) \cdot R_{\mathrm{f}}=0.55$ (cyclohexane/EtOAc 5:3); m.p. $=113.3{ }^{\circ} \mathrm{C} ;{ }^{1} \mathrm{H}$ NMR: $\delta=6.50(\mathrm{~d}, J=1.3 \mathrm{~Hz}, 1 \mathrm{H} ; \mathrm{H} 4), 5.53(\mathrm{qd}, J=1.7,6.9 \mathrm{~Hz}, 1 \mathrm{H} ; \mathrm{H} 5), 3.22$ $(\mathrm{dt}, J=3.9,14.1 \mathrm{~Hz}, 1 \mathrm{H} ; \mathrm{NCOCH}), 3.20(\mathrm{~m}, 1 \mathrm{H} ; \mathrm{H} 3), 2.34(\mathrm{dt}, J=4.7$, $14.1 \mathrm{~Hz}, 1 \mathrm{H}$; NCOCH), 2.22-2.31 (m, $2 \mathrm{H}$; $\left.\mathrm{OCOCH}_{2}\right), 2.10(\mathrm{~s}, 3 \mathrm{H}$; $\left.\mathrm{OCOCH}_{3}\right), 2.01(\mathrm{~m}, 1 \mathrm{H}), 1.76(\mathrm{~m}, 1 \mathrm{H}), 1.60(\mathrm{~m}, 1 \mathrm{H}), 1.49(\mathrm{~m}, 1 \mathrm{H}), 1.38$ (d, $\left.J=6.9 \mathrm{~Hz}, 3 \mathrm{H} ; \mathrm{CH}_{3} \mathrm{CHO}\right), 1.19-1.35(\mathrm{~m}, 4 \mathrm{H}) ;{ }^{13} \mathrm{C}$ NMR: $\delta=171.9$ $\left(\mathrm{OCOCH}_{2}\right), 171.1\left(\mathrm{NCOCH}_{2}\right), 169.0\left(\mathrm{OCOCH}_{3}\right), 163.8(\mathrm{C} 2), 74.8(\mathrm{C} 4)$, 65.4 (C5), $62.5(\mathrm{C} 3), 32.9\left(\mathrm{NCOCH}_{2}\right), 32.7\left(\mathrm{OCOCH}_{2}\right), 25.6\left(\mathrm{CH}_{2}\right), 25.4$ $\left(\mathrm{CH}_{2}\right), 25.3\left(\mathrm{CH}_{2}\right), 25.1\left(\mathrm{CH}_{2}\right), 20.8\left(\mathrm{OCOCH}_{3}\right), 18.3\left(\mathrm{CH}_{3} \mathrm{CHO}\right)$; IR: $\nu=1807,1743,1716 \mathrm{~cm}^{-1}$; HR-ESI-TOF-Mass (positive-mode): $\mathrm{m} / \mathrm{z}$ calcd for $\mathrm{C}_{15} \mathrm{H}_{21} \mathrm{NO}_{6}+\mathrm{Na}$ : 334.1267; found: 334.1252 .

\subsection{Single-crystal X-ray crystallography}

Compound $\mathbf{1 1}$ was recrystallized from ether/acetone (slow evaporation at room temperature). X-ray intensity data were

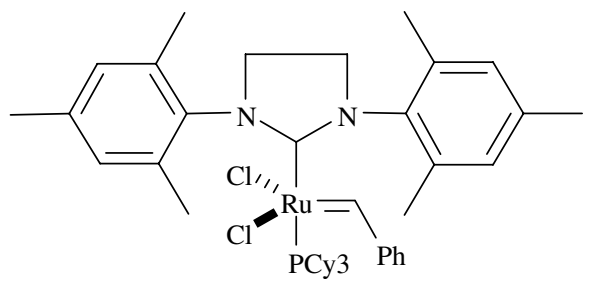

Scheme 6. Grubbs catalyst. 
collected at 298(2) K with a MAR345 image plate detector using Mo $\mathrm{K} \alpha(\lambda=0.71069 \AA)$ monochromatized radiation. The unit cell parameters were refined using all the collected spots after the integration process. Fig. 1 is drawn in the ORTEP style [69]. The structure was solved by direct methods with SHELXS97 and refined by full-matrix least-squares on $F^{2}$ using SHELXL97 [70]. All the nonhydrogen atoms were refined with anisotropic temperature factors. The hydrogen atoms were calculated with AFIX and included in the refinement with a common isotropic temperature factor. The structure has been deposited within the Cambridge Crystallographic data Centre, no CCDC 684061.

Crystal system $=$ monoclinic; space group $=P 2_{1}$; unit cell dimensions: $a=9.396(3) \AA ; ; \quad b=9.161(3) \AA$; $\quad c=9.815(3) \AA$; $\quad$ volume $=819.0(5) \AA^{3} ; Z=2 ; D x=1.25 \mathrm{~g} \mathrm{~cm}^{-3}$.

A total of 10605 reflections were collected of which 1962 were independent $\left(R_{\text {int }}=0.049\right) 1859$ observed reflections $(I>2.5 \sigma(I))$; $2 \theta \max =.44 .5^{\circ}$; final $R=0.046$ (all data); $w R 2=0.117 ; S=1.09$;

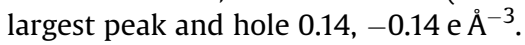

\subsection{NMR kinetic study}

Phosphate buffer $(1 \mathrm{~mL}, 50 \mathrm{mM}, \mathrm{pH} 8$ adjusted with $\mathrm{NaOH}$ solution) was freeze-dried and the residue was dissolved in $\mathrm{D}_{2} \mathrm{O}$ $(99.9 \%, 1 \mathrm{~mL})$. A solution of azetidinone $\left(25 \mu \mathrm{L}, 8.10^{-2} \mathrm{M}\right)$ in DMSO$d_{6}$ was diluted with deuteriated phosphate buffer $(475 \mu \mathrm{L})$ to give a final concentration of $4 \mathrm{mM}$. Chemical hydrolysis was followed by ${ }^{1} \mathrm{H}$ NMR at $500 \mathrm{MHz}$ as a function of time.

\subsection{Theoretical evaluation}

Conformational studies, calculations of heat of formation and reactivity versus hydroxyl anion were carried out using the wellestablished B3Lyp hybrid density functional [71] using the split valence polarized 6-31G(d) basis set [72].

Reactivity versus serine enzyme models were performed at the $a b$ initio RHF level using the minimal basis set MINI-1' [73]. All the calculations have been performed with the suite of programs Gaussian [74].

\subsection{Biochemical evaluation}

\subsubsection{Assay with PPE}

To a solution $(2 \mathrm{~mL})$ of substrate at $25^{\circ} \mathrm{C}(\mathrm{N}$-succinyl-L-alanyl-Lalanyl-L-alanyl-p-nitroanilide; $300 \mu \mathrm{M}$ in TRIS buffer, $100 \mathrm{mM}, \mathrm{pH}$ 7.5) and tested compound ( $20 \mu \mathrm{L} ; 10^{-2}-10^{-4} \mathrm{M}$ in $N$-methylpyrrolidone (NMP)), or solvent ( $20 \mu \mathrm{L}$ of NMP, for control), was added porcine pancreatic elastase (PPE from Sigma at $0.35 \mathrm{mg} / \mathrm{mL}$; $0.67 \mu \mathrm{L}$ of $6 \mu \mathrm{M}$ solution in acetate buffer, $50 \mathrm{mM}, \mathrm{pH} 5$; $[E]=200 \mathrm{nM})$. Absorbance at $410 \mathrm{~nm}$, corresponding to the appearance of $p$-nitroaniline (substrate hydrolysis product) was measured with a Varian Cary 3 BIO spectrophotometer, as a function of time. Tested concentrations of inhibitors were 100, 50, 25 and $1 \mu \mathrm{M}$.

The reversibility of the inhibition was controlled by the incubation/dilution method. Enzyme solution $(67 \mu \mathrm{L})$ and inhibitor solution $(20 \mu \mathrm{L})$ were incubated during 20,40 and $60 \mathrm{~min}$ before the addition of substrate solution $(2 \mathrm{~mL})$. Absorbance at $410 \mathrm{~nm}$ for different concentrations of inhibitor $(100,50,25$ and $1 \mu \mathrm{M})$ was measured as a function of time.

\subsubsection{Assay with TEM-1}

The assay mixture was prepared at $25^{\circ} \mathrm{C}$ from the substrate solution (nitrocefine at $1 \mathrm{mM}$ in phosphate buffer, $100 \mathrm{mM}, \mathrm{pH} 7$ containing 5\% DMSO; $100 \mu \mathrm{L})$ and the tested compound $\left(10^{-2}\right.$ $10^{-4} \mathrm{M}$ in DMSO; $\left.10 \mu \mathrm{L}\right)$, or solvent (10 $\mu \mathrm{L}$ DMSO, for control), diluted in phosphate buffer $(890 \mu \mathrm{L}, 50 \mathrm{mM}, \mathrm{pH} 7)$. At $t=0$, the enzyme solution was added (class A $\beta$-lactamase TEM-1 at $1.2 \mu \mathrm{M}$ in phosphate buffer, $50 \mathrm{mM}$; pH 7; $1 \mu \mathrm{L}$, [E]=1.2 nM). Absorbance at $486 \mathrm{~nm}$, corresponding to the appearance of nitrocefine hydrolysis product, was measured with a Varian Cary 3 BIO spectrophotometer, as a function of time. Tested concentrations of inhibitors were 100,10 and $1 \mu \mathrm{M}$. TEM-1 enzyme was obtained from the Unité de Biochimie (UCL, Louvain-la-Neuve), professors J. Fastrez and P. Soumillon.

\subsubsection{Assay with PBPs}

The tested enzymes $\left(\mathrm{R} 39, \mathrm{PBP}_{2 \mathrm{a}}, \mathrm{PBP}_{5 \mathrm{fm}}, \mathrm{PBP}_{2 \mathrm{x}}\right)$ were produced and purified at the University of Liège (Centre d'ingénierie des protéines, professors J-M. Frère, B. Joris and M. Galleni). The inhibition studies were performed at $30^{\circ} \mathrm{C}$ in sodium phosphate buffer ( $50 \mathrm{mM}, \mathrm{pH} 7$ ) containing $5 \%$ to $10 \% \mathrm{DMF}$ to ensure product solubility. In the case of $\mathrm{PBP}_{2 \mathrm{a}}$ and $\mathrm{PBP}_{5 \mathrm{fm}}, 0.5 \mathrm{M} \mathrm{NaCl}$ was added. Compounds were tested at $100 \mu \mathrm{M}$ concentration; experiments were performed in triplicate. Inhibitor $(100 \mu \mathrm{M})$ and protein $(0.8$ or $2.5 \mu \mathrm{M}$ ) were mixed and incubated for $16 \mathrm{~h}$. The residual free protein was counter labeled with fluorescein-labeled ampicillin $(25 \mu \mathrm{M})$ for $45 \mathrm{~min}$. Then, the reaction was stopped by addition of SDS-PAGE loading buffer and heating at $100^{\circ} \mathrm{C}$ for $4 \mathrm{~min}$. The reaction mixture was submitted to SDS-PAGE. The fluorescent complexes (formed by reaction of residual PBPs and ampicillin) were visualised using a Molecular Imager FX and quantified with the Quantity One Software of BIORAD. In each assay, background fluorescence was subtracted.

\section{Acknowledgements}

The authors acknowledge Prof. Jacques Fastrez (UCL) and Prof. Bernard Joris (ULg) for stimulating discussions, Dr. David Chapon (UCL) for NMR kinetics at $500 \mathrm{MHz}$, Stana Grubisic (ULg) for contribution in biochemical evaluation, and Sabrina Devouge (UCL) for able assistance in preparing the manuscript. This work has been supported by the PAI (Pôle d'Attraction Interuniversitaire, Belgium) - contract P5/33 "Protein structure and function in the postgenomic era". G.D. thanks the F.R.S. - F.N.R.S. (Fonds de la Recherche Scientifique, Belgium) for the financial support of the high performance computing systems installed at Liège and Louvain-la-Neuve. J.M-B. and G.D. are senior research associates of the F.R.S. - F.N.R.S.

\section{References}

[1] J.T.B.H. Jastrzebski, G. Van Koten, Penicillins, in: A.R. Katritzky (Ed.), Comprehensive Heterocyclic Chemistry (CHC II), 2nd ed. Elsevier, Oxford, UK, 1995, pp. 623-658 [Chapter 1.20].

[2] C. Hubschwerlen, $\beta$-lactam antibiotics, in: J.B. Taylor, D.J. Triggle (Eds.), Comprehensive Medicinal Chemistry, 2nd ed. Elsevier, Oxford, UK, 2007, pp. 479-517 [Chapter 7.17].

[3] J. Marchand-Brynaert, C. Brulé, Penicillins [Chapter 2.03], in: A.R. Katritzky, C.A. Ramsden, E.F.V. Scriven, R.J.K. Taylor (Eds.), Comprehensive Heterocyclic Chemistry (CHC III), 3rd ed. Elsevier, Oxford, UK, 2008, pp. 173-237.

[4] R.B. Woodward, Philos. Trans. R Soc. London (B) Biol. Sci. 289 (1980) 239.

[5] N.C. Cohen, J. Med. Chem. 26 (1983) 259.

[6] R.M. Sweet, L.F. Dahl, J. Am. Chem. Soc. 92 (1970) 5489.

[7] G. Burton, Bioorg. Med. Chem. Lett. 3 (1993) 2329.

[8] J.I. Mujika, J.M. Mercero, X. Lopez, J. Am. Chem. Soc. 127 (2005) 4445.

[9] J. Clayden, W.J. Moran, Angew. Chem. Int. Ed. 45 (2006) 7118.

[10] X.-F. Ren, M.I. Konaklieva, H. Shi, S. Dickey, D.V. Lim, J. Gonzalves, E. Turos, J. Org. Chem. 63 (1998) 8898.

[11] B. Alcaide, P. Almendros, C. Aragoncillo, M.C. Redondo, M. Rosario Torres, Chem-Eur. J. 12 (2006) 1539.

[12] L.N. Jungheim, D.B. Boyd, J.M. Indelicato, C.E. Pasini, D.A. Preston, W.E. Alborn Jr., J. Med. Chem. 34 (1991) 1732.

[13] J.E. Baldwin, G.P. Lynch, J. Pitlik, J. Antibiot. 44 (1991) 1.

[14] J.D. Buynak, A. Srinivasa Rao, G. Adam, S.D. Nidamarthy, H. Zhang, J. Am. Chem. Soc. 120 (1998) 6846.

[15] R.M. Williams, B.H. Lee, M.M. Miller, O.P. Anderson, J. Am. Chem. Soc. 111 (1989) 1073.

[16] J. Aszodi, D.A. Rowlands, P. Mauvais, P. Collette, A. Bonnefoy, M. Lampilas, Bioorg. Med. Chem. Lett. 14 (2004) 2489. 
[17] A.H. Berks, Tetrahedron 52 (1996) 331.

[18] A. Furstner, Angew. Chem. Int. Ed. 39 (2000) 3012

[19] T.M. Trnka, R.H. Grubbs, Acc. Chem. Res. 34 (2001) 18.

[20] This strategy has been already applied for the preparation of 1,4-fused ring $\beta$-lactams. See for examples: A.G. Barrett, S.P.D. Baugh, D.C. Braddock, K. Flack, V.C. Gibson, M.R. Giles, E.L. Marshall, P.A. Procopiou, A.J.P. White, D.J. Williams J. Org. Chem. 63 (1998) 7893;

C.A. Tarling, A.B. Holmes, R.E. Markwell, N.D. Pearson, J. Chem. Soc. Perkin Trans. 1 (1999) 1695;

A.G. Barrett, M. Ahmed, S.P. Baker, S.P.D. Baugh, D.C. Braddock, P.A. Procopiou A.J.P. White, D.J. Williams, J. Org. Chem. 65 (2000) 3716;

N. Desroy, F. Robert-Peillard, J. Toueg, C. Hénaut, R. Duboc, M.-N. Rager M. Savignac, J.-P. Genêt, Synthesis 16 (2004) 2665

[21] For HLE (human leucocyte elastase) inhibitors, see for examples: D.A. Burnett Curr. Med. Chem. 11 (2004) 1873;

B. Macchia, D. Gentili, M. Macchia, F. Mamone, A. Martinelli, E. Orlandini, A. Rossello, G. Cercignani, R. Pierotti, M. Allegretti, C. Asti, G. Caselli, Eur. J. Med. Chem. 35 (2000) 53;

P.E. Finke, S.K. Shah, D.S. Fletcher, K.M. Ashe, A.L. Maycock, D.G. Osinga, D.J. Underwood, H. Weston, P. Davies, J.B. Doherty, J. Med. Chem. 38 (1995) 2449;

D.J. Underwood, B.G. Green, R. Chabin, S. Mills, J.B. Doherty, P.E. Finke, M. Mc Coss, S.K. Shah, C.S. Burgey, T.A. Dickinson, P.R. Griffin, T.E. Lee, K.M. Swiderek T. Covey, W.M. Westler, W.B. Knight, Biochemistry 34 (1995) 14344; S.K. Shah, C.P. Dorn Jr., P.E. Finke, J.J. Hale, W.K. Hagmann, K.A. Brause, G.O. Chandler, A.L. Kissinger, B.M. Ashe, H. Weston, W.B. Knight, A.L. Maycock, P.S. Dellea, D.S. Fletcher, K.M. Hand, R.A. Mumford, D.J. Underwood, J.B. Doherty, J. Med. Chem. 35 (1992) 3745

[22] see for examples: C. Yoakim, W.W. Ogilvie, D.R. Cameron, C. Chabot, I. Guse B. Haché, J. Naud, J.A. O’Meara, R. Plante, R. Déziel J. Med. Chem. 41 (1998) 2882 For HCMV (human cytomegalovirus) protease inhibitors;

R. Déziel, E. Malenfant, Bioorg. Med. Chem. Lett. 8 (1998) 1437;

P.R. Bonneau, F. Hasani, C. Plouffe, E. Malenfant, S.R. LaPlante, I. Guse, W.W. Ogilvie, R. Plante, W.C. Davidson, J.L. Hopkins, M.G. Morelock M.G. Cordingley, R. Déziel, J. Am. Chem. Soc. 121 (1999) 2965.

[23] For PSA (prostate specific antigen) inhibitors, see for examples: R.M. Adlington, J.E. Baldwin, B. Chen, S.L. Cooper, W. Mc Coull, G.J. Pritchard Bioorg. Med. Chem. Lett. 7 (1997) 1689;

R.M. Adlington, J.E. Baldwin, G.W. Becker, B. Chen, L. Chen, S.L. Cooper R.B. Hermann, W. Mc Coull, A.N. Mc Nulty, B.L. Neubauer, G.J. Pritchard, J. Med. Chem. 44 (2001) 1491

[24] For human chymase inhibitors, see for example: Y. Aoyama, M. Uenaka, M. Kii, M. Tanaka, T. Konoike, Y. Hayasaki-Kajiwara, N. Noya, M. Nokajima Bioorg. Med. Chem. 9 (2001) 3065.

[25] EJ. Corey, A. Venkateswarlu, J. Am. Chem. Soc 94 (1972) 6190.

[26] M. Murakami, T. Aoki, W. Nagata, Heterocycles 30 (1990) 567.

[27] Y.M. Ahn, K. Yang, G.I. Georg, Org. Lett. 3 (2001) 1411

[28] A. Wagner, R. Flaig, B. Dittrich, H. Schmidt, T. Koritsanszky, P. Luger, Chem. Eur. J. 10 (2004) 2977.

[29] P. Dapporto, P. Paoli, P. Rossi, M. Altamura, E. Perrotta, Struct Chem. 10 (1999) 311.

[30] R. Lopez, M.I. Menendez, N. Diaz, D. Suarez, P. Campomanes, D. Ardura, T.L. Sordo, Curr. Org. Chem. 10 (2006) 805 and references cited therein.

[31] J. Pitarch, M.F. Ruiz-Lopez, J.L. Pascual-Ahuir, E. Silla, I. Tunon, J. Phys. Chem. B. 101 (1997) 3581

[32] W.N. Olmstead, J.I. Brauman, J. Am. Chem. Soc. 99 (1977) 4219.

[33] J. Frau, J. Donoso, F. Munoz, F. Garcia Blanco, Helv. Chim. Acta 80 (1997) 739.

[34] I. Massova, P.A. Kollman, J. Phys. Chem. B. 103 (1999) 8628.

[35] M.I. Page, Adv. Phys. Org. Chem. 23 (1987) 165.

[36] M.I. Page, Acc. Chem. Res. 17 (1984) 144

[37] W.I. Tsang, N. Ahmed, K. Hemming, M.I. Page, Can. J. Chem. 83 (2005) 1432.

[38] J. Pitarch, M.F. Ruiz-Lopez, E. Silla, J.L. Pascual-Ahuir, I. Tunon, J. Am. Chem. Soc. 120 (1998) 2146.

[39] G. Dive, D. Dehareng, D. Peeters, Int. J. Quant. Chem. 58 (1996) 85

[40] S. Gérard, M. Galleni, G. Dive, J. Marchand-Brynaert, Bioorg. Med. Chem. 12 (2004) 129 and references cited therein.

[41] G. Dive, D. Dehareng, Int. J. Quant. Chem. 73 (1999) 161.

[42] The reactive species have been calculated at the Hartree-Fock level as the sum of the energies of the isolated partners, and not as a pre-complex moving toward the transition state. Accordingly, the sum of entropies of isolated partners is significantly more higher than the entropy of an intermediate complex and this leads to an over-estimation of the free energy differences.

[43] M.I. Page, The mechanism of reactions of $\beta$-lactams [Chapter 4], in: M.I. Page (Ed.), The Chemistry of $\beta$-Lactams, Blackie Academic and Professional, London, 1992, pp. 129-147.
[44] A. Matagne, J. Lamotte-Brasseur, J.M. Frère, Biochem. J. 330 (1998) 581.

[45] J.M. Frère, M. Nguyen-Distèche, J. Coyette, B. Joris, Mode of action: interaction with the penicillin binding proteins [Chapter 5], in: M.I. Page (Ed.), The Chemistry of $\beta$-Lactams, Blackie Academic and Professional, London, 1992, pp. 148-197.

[46] P.E. Finke, B.M. Ashe, W.B. Knight, A.L. Maycock, M.A. Navia, S.K. Shah, K.R. Thompson, D.J. Underwood, H. Weston, M. Zimmerman, J.B. Doherty, J. Med. Chem. 33 (1990) 2522.

[47] S.N. Maiti, D.E. Woods, A.M. Cantin, Drugs Future 6 (1998) 635.

[48] C. Beauve, G. Tjoens, R. Touillaux, J. Lamotte-Brasseur, J. Marchand-Brynaert, J. Fastrez, Eur. J. Org. Chem. (1999) 1441.

[49] S. Gérard, G. Nollet, J. Vande Put, J. Marchand-Brynaert, Bioorg. Med. Chem. 10 (2002) 3955.

[50] S. Gérard, G. Dive, B. Clamot, R. Touillaux, J. Marchand-Brynaert, Tetrahedron 58 (2002) 2423.

[51] I. Vergely, N. Bogetto, V. Okochi, S. Golpayegani, M. Reboud-Ravaux, R. Kobaiter, R. Joyeau, M. Wakselman, Eur. J. Med. Chem. 30 (1995) 199.

[52] R.J. Cvetovich, M. Chartain, F.W. Hartner, C. Roberge Jr., J.S. Amato E.J.J. Grabowski, J. Org. Chem. 61 (1996) 6575.

[53] E. Sauvage, R. Herman, S. Petrella, C. Duez, F. Bouillenne, J.M. Frère, P. Charlier J. Biol. Chem. 280 (2005) 31249.

[54] E. Fonzé, M. Vermeire, M. Nguyen-Distèche, R. Brasseur, P. Charlier, J. Biol. Chem. 274 (1999) 21853.

[55] P. Macheboeuf, C. Contreras-Martel, V. Job, O. Dideberg, A. Dessen, FEMS Microbiol. Rev. 30 (2006) 673

[56] M.S. Wilke, A.L. Lovering, N.C.J. Strydnaka, Curr. Opin. Microbiol. 8 (2005) 525.

[57] K. Poole, Cell. Mol. Life Sci. 61 (2004) 2200.

[58] M.C. Enright, D.A. Robinson, G. Randle, E.J. Feil, H. Grundmann, B.G. Spratt, Proc. Nat. Acad. Sci. USA 99 (2002) 7687.

[59] D. Lim, N.C. Strynadka, Nat. Struct. Biol. 9 (2002) 870.

[60] E. Sauvage, F. Kerff, E. Fonzé, R. Herman, B. Schoot, J.-P. Marquette, Y. Taburet, D. Prevost, J. Dumas, G. Leonard, P. Stefanic, J. Coyette, P. Charlier, Cell. Mol. Life Sci. 59 (2002) 1223.

[61] A. Dessen, N. Mouz, E. Gordon, J. Hopkins, O. Dideberg, J. Biol. Chem. 276 (2001) 45106.

[62] R. Carapito, L. Chesnel, T. Vernet, A. Zapun, J. Biol. Chem. 281 (2005) 1771.

[63] L. Pernot, L. Chesnel, A. Le Gouellec, J. Croizé, T. Vernet, O. Dideberg, A. Dessen, J. Biol. Chem. 279 (2004) 16463.

[64] M. Kurazono, T. Ida, K. Yamada, Y. Hirai, T. Maruyama, E. Shitara, M. Yonezawa, Antimicrob. Agents Chemother. 48 (2004) 2831.

[65] H.S. Sader, T.R. Fritsche, K. Kaniga, Y. Ge, R.N. Jones, Antimicrob. Agents Chemother. 49 (2005) 3501.

[66] I. Plantan, L. Selic, T. Mesar, P.S. Anderluh, M. Oblak, A. Prezelj, L. Hesse, M. Andrejasic, M. Vilar, D. Turk, A. Kocijan, T. Prevec, G. Vilfan, D. Kocjan, A. Copar, U. Urleb, T. Solmajer, J. Med. Chem. 50 (2007) 4113.

[67] S.G. Waley, $\beta$-Lactamase: mechanism of action [Chapter 6], in: M.I. Page (Ed.), The Chemistry of $\beta$-Lactams, Blackie Academic and Professional, London, 1992 pp. 198-228.

[68] R.F. Pratt, $\beta$-Lactamase: inhibition [Chapter 7], in: M.I. Page (Ed.), The Chemistry of $\beta$-Lactams, Blackie Academic and Professional, London, 1992, pp. 229-271.

[69] A.L. Spek, PLATON, Molecular Geometry Program, University of Utrecht, The Netherlands, 1998

[70] G.M. Sheldrick, SHELXS97 and SHELXL97: Program for the Solution and Refinement of Crystal Structures, University of Göttingen, Germany, 1997.

[71] A.D. Becke, J. Chem. Phys. 98 (1993) 5648

[72] W.J. Hehre, R. Ditchfield, J.A. Pople, J. Chem. Phys. 56 (1972) 2257.

[73] G. Dive, D. Dehareng, J.M. Ghuysen, Theor. Chim. Acta 85 (1993) 409.

[74] M.J. Frisch, G.W. Trucks, H.B. Schlegel, G.E. Scuseria, M.A. Robb, J.R. Cheeseman, J.A. Montgomery Jr., T. Vreven, K.N. Kudin, J.C. Burant, J.M. Millam, S.S. Iyengar, J. Tomasi, V. Barone, B. Mennucci, M. Cossi, G. Scalmani, N. Rega, G.A. Petersson, H. Nakatsuji, M. Hada, M. Ehara, K. Toyota, R. Fukuda, J. Hasegawa, M. Ishida, T. Nakajima, Y. Honda, O. Kitao, H. Nakai, M. Klene, X. Li, J.E. Knox, H.P. Hratchian, J.B. Cross, C. Adamo, J. Jaramillo, R. Gomperts, R.E. Stratmann, O. Yazyev, A.J. Austin, R. Cammi, C. Pomelli, J.W. Ochterski, P.Y. Ayala, K. Morokuma, G.A. Voth, P. Salvador, J.J. Dannenberg, V.G. Zakrzewski, S. Dapprich, A.D. Daniels, M.C. Strain, O. Farkas, D.K. Malick, A.D. Rabuck, K. Raghavachari, J.B. Foresman, J.V. Ortiz, Q. Cui, A.G. Baboul, S. Clifford, J. Cioslowski, B.B. Stefanov, G. Liu, A. Liashenko, P. Piskorz, I. Komaromi, R.L. Martin, D.J. Fox, T. Keith, M.A. Al-Laham, C.Y. Peng, A. Nanayakkara, M. Challacombe, P.M.W. Gill, B. Johnson, W. Chen, M.W. Wong, C. Gonzalez, J.A. Pople, Gaussian 03, Revision C.02, Gaussian, Inc., Wallingford, CT, 2004. 